\title{
sciendo
}

\section{SUPPLEMENTATION OF BILE ACIDS AND LIPASE IN BROILER DIETS FOR BETTER NUTRIENT UTILIZATION AND PERFORMANCE: POTENTIAL EFFECTS AND FUTURE IMPLICATIONS - A REVIEW}

\author{
Muhammad Adeel Arshad ${ }^{1}$, Faiz-ul-Hassan ${ }^{1}$, Shaukat Ali Bhatti' ${ }^{1}$, Muhammad Saif-ur Rehman ${ }^{1}$, \\ Wasim Yousaf ${ }^{1}$, Gulfam Younus ${ }^{1}$, Ozge Sizmaz ${ }^{2}$, Muhammad Qamar Bilal ${ }^{1 \star}$ \\ ${ }^{1}$ Institute of Animal and Dairy Sciences, Faculty of Animal Husbandry, University of Agriculture, \\ Faisalabad-38040, Pakistan \\ ${ }^{2}$ Department of Animal Nutrition and Nutritional Diseases, Faculty of Veterinary Medicine, \\ Ankara University, Ankara, 06110, Turkey \\ •Corresponding author:drqamarbilal@gmail.com
}

\begin{abstract}
Bile acids are used for better emulsification, digestion and absorption of dietary fat in chicken, especially in early life. Similarly, exogenous lipases have also been used for the improvement of physiological limitation of the chicken digestive system. Owing to potential of both bile acids and lipases, their use has been increased in recent years, for better emulsification of dietary fat and improvement of growth performance in broilers. In the past, pancreatic lipases were used for supplementation, but recently, microbial lipase is getting attention in poultry industry as a hydrolysis catalyst. Bile acids strengthen the defence mechanism of body against bacterial endotoxins and also play a key role in lipid regulation and sugar metabolism as signaling molecules. It has been demonstrated that bile acids and lipases may improve feed efficiency by enhancing digestive enzyme activity and ultimately leading to better fat digestion and absorption. Wide supplemental range of bile acids $(0.004 \%$ to $0.25 \%)$ and lipases $(0.01 \%$ to $0.1 \%)$ has been used in broiler diets for improvement of fat digestibility and their performance. Combinations of different bile acids have shown more potential to improve feed efficiency (by $7.14 \%)$ even at low $(0.008 \%)$ levels as compared to any individual bile acid. Lipases at a lower level of $0.03 \%$ have exhibited more promising potential to improve fat digestibility and feed efficiency. However, contradicting results have been published in literature, which needs further investigations to elucidate various nutritional aspects of bile acids and lipase supplementation in broiler diet. This review focuses on providing insight on the mechanism of action and potential application of bile acids and lipases in broiler diets. Moreover, future implications of these additives in poultry nutrition for enhancing nutrient utilization and absorption are also discussed.
\end{abstract}

Key words: bile acids, broiler, digestibility, fat, lipase enzyme, meat quality

Lipids are hydrocarbons (highly reduced molecules) which are generally insoluble in water and soluble in organic solvents (Gunstone, 2012). They are consid- 
ered principal energy reserves in the animal body. Oxidation of fats releases 2.25 times more energy than sugars and proteins. Generally, lipids are classified together as ether extract during proximate analysis of feedstuff, known as crude fats (Wu, 2018). Fats are also called triacylglycerols (TAGs) or triglycerides because all three hydroxyl groups of glycerol are esterified to a glycerol backbone (Mead, 1986). In most of the animal feeds, dietary fat makes up 98\% of total lipids (Pond et al., 2004). Fats have protective functions in the skin and subcutaneous tissues. Fat contents of the body are low at birth but increase with age (Conde-Aguilera et al., 2013). Among fats, TAGs are the main form of energy storage in animal body (Ridgway and McLeod, 2016).

Higher energy requirements of broilers compel nutritionists to design diets with high oil contents. Generally, animal fats and vegetable oils are used in broiler diets to increase their energy density (Leeson and Summers, 2005; Fascina et al., 2009; Abudabos, 2014). Energy is considered as a major dietary component, which can affect the utilization of nutrients at different densities (Cho et al., 2012). According to $\mathrm{Wu}$ (2018), fat contents (on as-fed basis) in diets of broiler vary at different stages of age; for example, $5 \%$ for starter phase (1-21 days), $6 \%$ for grower phase (22-35 days) and $8 \%$ for finisher phase (36-49 days). It can also vary according to different environmental conditions.

Addition of fat in poultry diets improves palatability, provides energy, increases absorption of fat-soluble vitamins and nutrients in the gastrointestinal tract through reduced passage rate of digesta (Mateos et al., 1982; NRC, 1994; Baião and Lara, 2005; Febel et al., 2008; Firman et al., 2008). Diets with similar nutritive values containing oil have shown better growth than birds fed diets without oil (Elzobier et al., 2016). However, adding fat in broiler diets in their early age also poses negative impacts due to the limited ability of broiler to digest them and thus compromises growth performance (Wiseman and Lewis, 1998). Adverse effects on other nutrients intake and body composition of broiler have also been observed in response to higher dietary fat. Immature physiological function in early life of broilers can lead to low production of bile acids and pancreatic lipase that makes them vulnerable to negative impacts of dietary fat (Wiseman and Lewis, 1998; Classen, 2017; Pantaya et al., 2020). That is why improving fat utilization is essential for better performance of broiler.

This review aims to highlight the nutritional relevance and advantages of supplementation of bile acids and lipases in broiler diets to improve nutrient utilization and growth performance, especially in high-density diets.

\section{Strategies to improve fat utilization}

Ability of young birds to digest and absorb fat is comparatively less than mature ones (Wiseman and Salvador, 1989). The lower ability of fat digestion during early age is mainly due to insufficient production of pancreatic lipase and endogenous bile (Figure 1). 


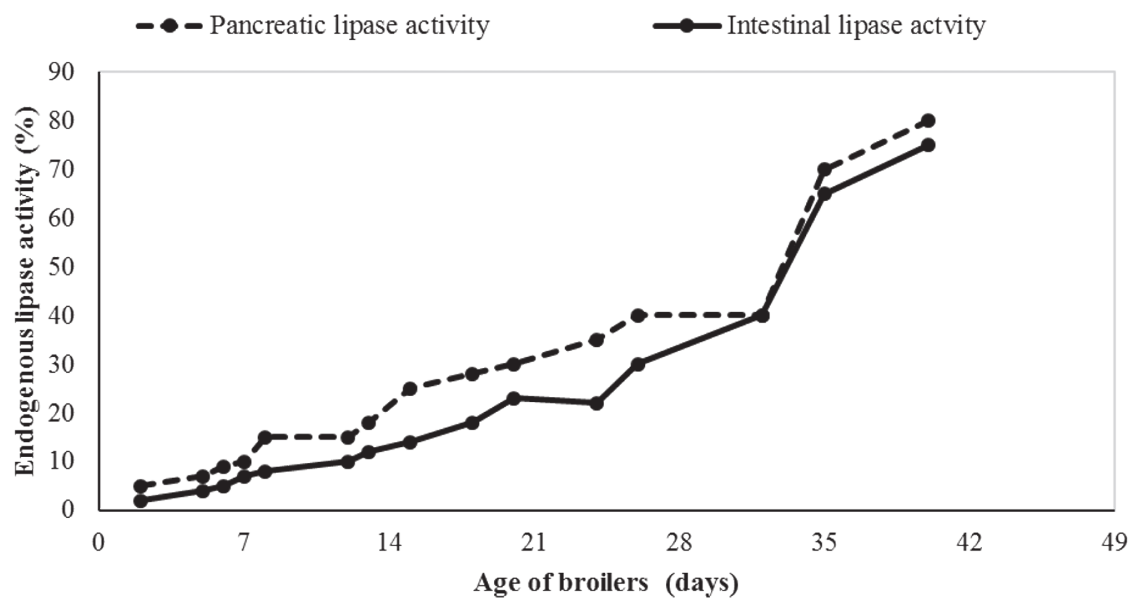

Figure 1. Relationship between age and endogenous lipase activity in broilers (data from Krogdahl and Sell, 1989; Nir et al., 1993; Dunnington and Siegel, 1995; Maiorka et al., 2004; Scanes, 2015 were used to generate this figure)

Fats emulsification is required for activity of a lipolytic enzyme because it is insoluble in aqueous solution of gastrointestinal tract (GIT). Therefore, emulsifiers supplementation is required in early life of poultry birds. Exogenous bile acids and lipase enzymes are used for proper fat utilization (Siyal et al., 2017).

\section{Use of emulsifiers}

Emulsifying agents (emulsifiers) are commonly used as stabilizer in water and oil emulsion. Emulsifiers break down oil and help in dispersion of oil droplets throughout water to make micelle formation. Emulsification can be affected by different characteristics of fat such as fat saturation, fatty acid position and chain length in triglycerides (Gu and Li, 2003). Emulsifying agents can be categorized into natural and synthetic groups. Natural emulsifiers include components of food material and are synthesized in the animal body. Synthetic emulsifiers are synthesized chemically for emulsification process. Common emulsifiers used in the poultry industry are listed in Table 1. Different emulsifiers possess different abilities of fat emulsification and utilization. Bile salts or bile acids are also one of them, focused here as an emulsifier in broiler diet to enhance fat utilization.

\section{Bile acids, their synthesis and biological functions}

Bile acids (C24) are organic components of bile usually synthesized from cholesterol in hepatocytes. Different amphipathic acidic steroids are involved in the formation of bile acid pool (Marin, 2008; Hofmann and Hagey, 2014). Bile acids are conjugated with glycine and taurine, and in some animals, with sulfate $\left(\mathrm{SO}_{4}\right)$. Due to their conjugation, molecular weight of fat-soluble compounds increases, which make them further water-soluble and less prone to precipitate in a watery medium. Bile acids are considered as steroid molecules that are involved in digestion and absorption of fat and hydrophobic compounds in the intestinal lumen. 


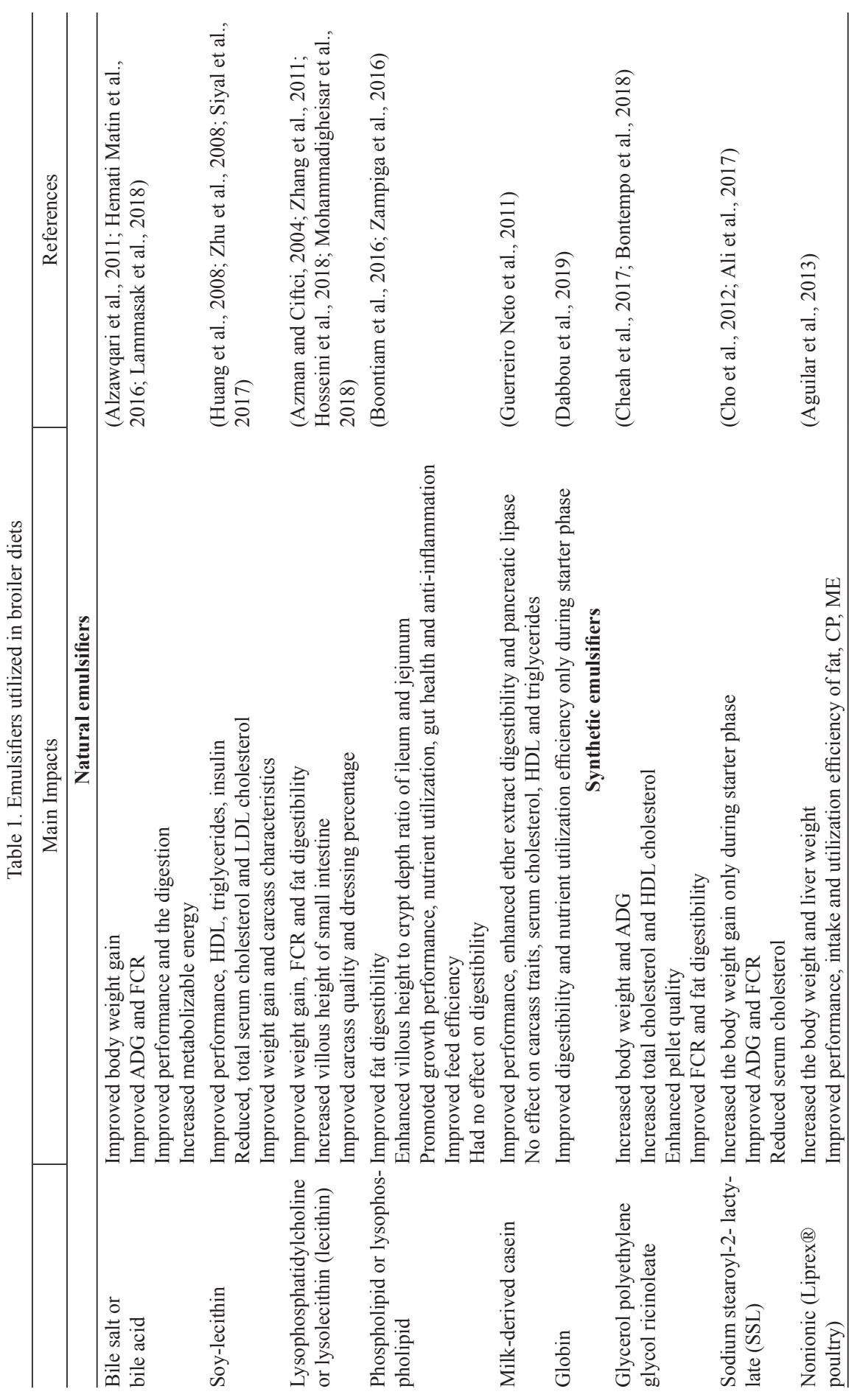


Bile acids have specified features: the steroid nucleus, derived from a saturated tetracyclic hydrocarbon perhydrocyclopentanophenanthrene system formed by three six-membered rings (A, B and C) and a five-membered ring (D), shortened side chain (C5) in comparison of cholesterol (C8), and are acidic in nature, usually because of the carboxylic group which terminate the side chain branched to ring D (Monte et al., 2009; Marin et al., 2016). Sodium and potassium salts of bile acids are known as bile salts and give alkaline milieu to bile. While, these two terms, bile acids and bile salts are typically used interchangeably, bile salts are usually considered to be better emulsifying agents than bile acids in chicken. To increase solubility of water bile salt, the terminal carboxyl group of bile acids (approximately 98\%) is conjugated with taurine or glycine before secretion from the liver (Lindsay and March, 1967). Different animal species have a different amount of glycine and taurine (Washizu et al., 1991). Bile acids are conjugated with glycine in herbivores, taurine in carnivores, and both taurine and glycine in omnivores (Agellon, 2008). Rate of biliary secretion is faster $(24.2 \mu \mathrm{L} / \mathrm{min})$ in broiler (Lisbona et al., 1981).

Bile acids as amphipathic molecules have a hydrophilic side $(\alpha$-side) on one end and hydrophobic side $(\beta$-side) on another, which gives distinctive detergent features to bile acids. Bile acids form mixed micelles with biliary phospholipids to stimulate biliary lipid secretion, which allows solubilization in bile of cholesterol and other lipophilic compounds (Coleman, 1987; Coello et al., 1996). Besides, bile is required for intestinal absorption of vitamin $\mathrm{D}_{3}$ in chicks, and this indirectly improves absorption of calcium as sparingly soluble calcium hydrogen phosphate (Webling and Holdsworth, 1965; Sanyal et al., 1994). Secretion of bile acids into bile canaliculi generates an osmotic pressure that accounts for the so-called bile-acid-dependent fraction of bile flow. At the intestinal level, bile acids are known to modulate secretion of pancreatic enzyme and cholecystokinin release (Koop et al., 1996). Other lipids secreted into bile are lecithin (phosphatidylcholine), free cholesterol and bile pigments (bilirubin, glucuronides). Furthermore, continuous flow of bile acids forms a potent antimicrobial barrier, avoiding both bacterial penetrations of biliary tree and in the small intestine (Begley et al., 2005; Engelking, 2011).

Bile acids play an essential role in the defence mechanism against bacterial endotoxins (Kocsar et al., 1969). Moreover, bile acids can reduce endotoxin absorption (Sheen-Chen et al., 2002), repair physical damage to the intestinal mucosa (Kamiya et al., 2004), and inhibit noxious bacteria, such as E. coli and Clostridium botulinum (Huhtanen, 1979). In addition to their role in managing nutrients, bile acids also play a key role in lipid regulation and sugar metabolism as signalling molecules (Watanabe et al., 2006; Russell, 2009). Recent studies have revealed that bile acids could regulate the expression of hepatic lipogenic genes and enhance intestinal lipase activity in broilers (Piekarski et al., 2016; Ge et al., 2018), but the underlying mechanism is still unkown.

Bile acids are synergistically produced by endogenous metabolic and symbiotic intestinal microbiota. The process is associated with the catalytic oxidation of cholesterol in liver and transformation of intestinal microbiota. Complex scenario related to bile acid biosynthesis, enterohepatic circulation and interactions with ileal and liver receptors are shown in Figure 2. Complex molecular mechanisms involve 
different nuclear receptors, such as farnesoid $\mathrm{X}$ receptor, retinoid $\mathrm{X}$ receptor, small heterodimer partner, liver receptor homologous-1 and liver X receptor (Garruti et al., 2012). In liver, primary bile acids (CA, CDCA) are mainly synthesized from cholesterol by the rate-limiting microsomal enzyme (alternative pathway). Bile acids are conjugated to taurine or glycine mainly via bile acid CoA synthase and BA-CoAamino acid $\mathrm{N}$-acetyltransferase, secreted into bile. Many intracellular reactions of various organelles (mitochondria, endoplasmic reticulum, cytosol, and peroxisomes) of hepatocytes are involved in bile acid synthesis from cholesterol (Lefebvre et al., 2009).

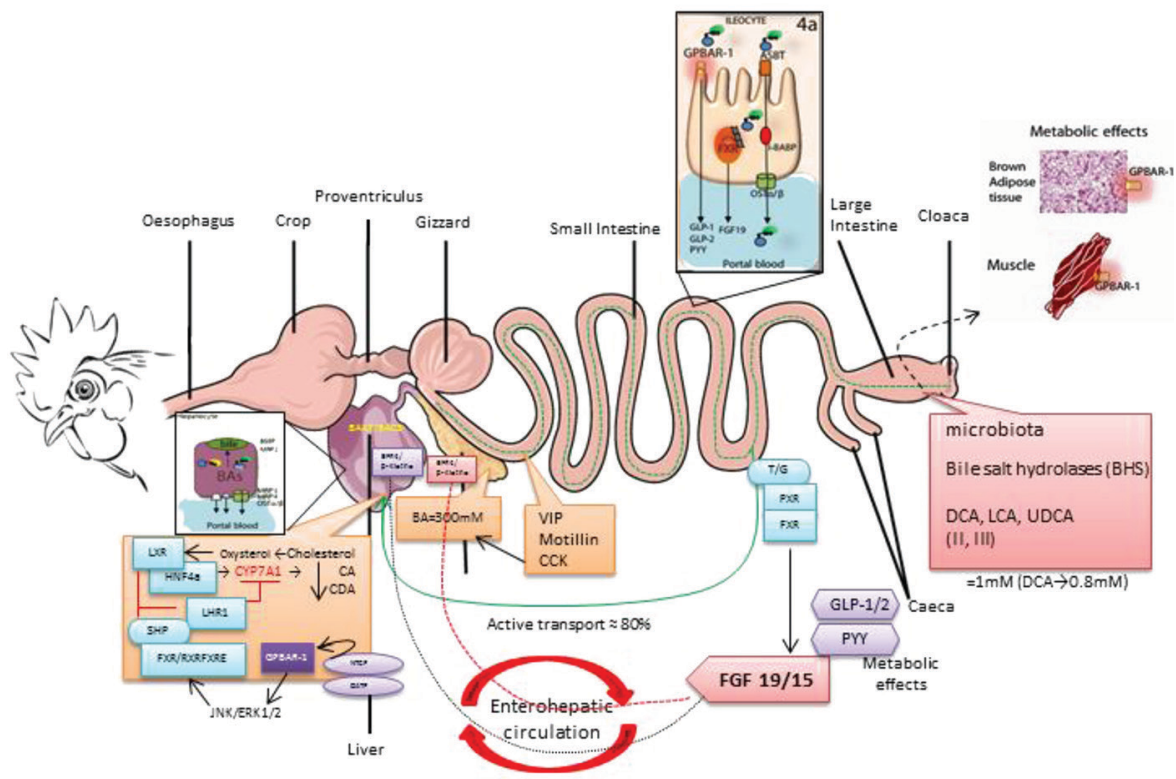

$\mathrm{CA}=$ cholic acid; $\mathrm{CDA}=$ chenodeoxycholic acid; $\mathrm{DCA}=$ deoxycholic acid; LCA = lithocholic acid; $\mathrm{UDCA}=$ ursodeoxycholic acid; FXR $=$ farnesoid $\mathrm{X}$ receptor; $\mathrm{RXR}=$ retinoid $\mathrm{X}$ receptor; $\mathrm{SHP}=\mathrm{small}$ heterodimer partner; LRH-1 = liver receptor homologous-1; LXR = liver X receptor; BACS = bile acid CoA synthase; BAAT = bile acid CoA-amino acid $\mathrm{N}$-acetyltransferase; $\mathrm{BSEP}=$ bile salt export pump; $\mathrm{MRP}=$ multidrug resistance-associated protein; $\mathrm{CCK}=$ cholecystokinin; $\mathrm{VIP}=$ vaso-intestinal peptide; FGF = fibroblast growth factor; GPBAR $=$ G protein-coupled receptor; PYY = peptide YY; GLP = glucagon-like peptide; ASBT = apical sodium dependent bile acid transporter; I-BABP = ileal bile acid binding protein; OST $=$ organic solute transporter; JNK/ERK $=$ Jun N-terminal kinase/extracellular signal regulated kinase.

Figure 2. Bile acid biosynthesis, enterohepatic circulation and function through their receptors in the liver and intestine (adapted from Di Ciaula et al., 2018)

Enterohepatic circulation involves recirculation of bile acids (95\%) into liver from terminal ileum (Hurwitz et al., 1973). Remaining 5\% bile salts (acids) goes into large intestine for further modifications by bacterial enzymes (Devlin, 2006). Here, biochemical reactions mediate deconjugation (removal of glycine or taurine) and removal of one hydroxyl group from the primary bile acids. Resultant products of 
dehydroxylation are called secondary bile acids (Wu, 2018). Usually, bile acids are comprised of primary bile acids and secondary bile acids. Almost all mammals, birds and some fish have bile acids of C24 compounds, but ancient mammals (elephants and manatees), reptiles and some aquatic animals have bile acids of C27 compounds (Hofmann, 1999; Agellon, 2008; Hagey et al., 2010; Kurogi et al., 2011). The C27 bile acids contain the $\mathrm{C} 8$ side chain of cholesterol, while the $\mathrm{C} 24$ bile acids have a truncated C5 side chain. Due to complex anatomy of birds, relatively insufficient information is recognized about biliary secretion. Primary bile acids in chicken and turkeys are chenodeoxycholyltaurine and cholyltaurine, while in ducks, chenodeoxycholyltaurine and phocaecholyltaurine are considered as predominant bile acids (Elkin et al., 1990). A list of different bile acids is shown in Table 2, according to their prevalence in different species.

Table 2. Occurrence of bile acids in different species

\begin{tabular}{|c|c|c|c|}
\hline Trivial Name & Type & Occurrence (Species) & References \\
\hline 1 & 2 & 3 & 4 \\
\hline Chenodeoxycholic acid & $\mathrm{P}$ & Bear, hamster, horse, human, pig & (Hofmann et al., 2010) \\
\hline Cholic acid & $\mathrm{P}$ & $\begin{array}{l}\text { Bear, cat, cattle, chicken, hamster, } \\
\text { human, rodents }\end{array}$ & $\begin{array}{l}\text { (Pedersen and Gustafsson, 1980; } \\
\text { Hagey et al., 1997) }\end{array}$ \\
\hline Hyocholic acid & $\mathrm{P}$ & pigs & $\begin{array}{l}\text { (Cantafora et al., 1986; Guertin } \\
\text { et al., 1995) }\end{array}$ \\
\hline$\beta$-Muricholic acid & $\mathrm{P}$ & Rodents & $\begin{array}{l}\text { (Rodrigues et al., 1996; Kakiy- } \\
\text { ama et al., 2004) }\end{array}$ \\
\hline Lithocholic acid & $\mathrm{S}$ & Bear, hamster, human, pig & (Rossi et al., 1987) \\
\hline Deoxycholic acid & $\mathrm{S}$ & $\begin{array}{l}\text { Bear, cat, cattle, chicken, dog, } \\
\text { hamster, human, rodents, rabbit, }\end{array}$ & $\begin{array}{l}\text { (Washizu et al., 1991; Guertin et } \\
\text { al., 1995; Wang et al., 2003) }\end{array}$ \\
\hline Ursodeoxycholic acid & $\mathrm{S}$ & Bear & (Hagey et al., 1997) \\
\hline Hyodeoxycholic acid & $\mathrm{S}$ & Pig & (Cantafora et al., 1986) \\
\hline Phocaecholic acid & $\mathrm{P}$ & Sea mammals, birds & (Murphy et al., 2001) \\
\hline Haemulcholic acid & $\mathrm{P}$ & Fish & $\begin{array}{l}\text { (Hoshita, 1967; Anderson et al., } \\
\text { 1980; Goto et al., 2003; Hagey et } \\
\text { al., 2010) }\end{array}$ \\
\hline Bitocholic acid & $\mathrm{S}$ & Snakes & (Bergström et al., 1960) \\
\hline Lagodeoxycholic acid & $\mathrm{S}$ & Nutria, bear & (Hagey et al., 1997) \\
\hline Ursocholic acid & $\mathrm{P}, \mathrm{S}$ & Humans, bear & (Ridlon et al., 2006) \\
\hline$\alpha$-muricholic acid & $\mathrm{S}$ & Rodents & (Merrill et al., 1996) \\
\hline$\beta$-muricholic acid & $\mathrm{P}$ & Rodents & (Kuramoto et al., 1987) \\
\hline$\omega$-muricholic acid & $\mathrm{P}, \mathrm{S}$ & Rodents & (Borgstrom et al., 1986) \\
\hline Murideoxycholic acid & $\mathrm{S}$ & Rodents & $\begin{array}{l}\text { (He et al., 2003; Kakiyama et } \\
\text { al., 2004) }\end{array}$ \\
\hline Vulpecholic acid & $\mathrm{P}$ & Marsupials & $\begin{array}{l}\text { (Lee et al., 1987; Kakiyama et } \\
\text { al., 2007) }\end{array}$ \\
\hline
\end{tabular}


Table 1 - contd.

\begin{tabular}{|c|c|c|c|}
\hline 1 & 2 & 3 & 4 \\
\hline Cygnocholic acid & $\mathrm{P}$ & Swans & (Kakiyama et al., 2006) \\
\hline Avicholic acid & $\mathrm{P}$ & Birds & (Hackett et al., 2008) \\
\hline Avideoxycholic acid & $\mathrm{S}$ & Birds & (Livezey and Zusi, 2007) \\
\hline $\begin{array}{l}\text { Norchenodeoxycholic } \\
\text { acid }\end{array}$ & $\mathrm{P}$ & Pinnipeds & (Hellou et al., 1988) \\
\hline $\begin{array}{l}\text { Allochenodeoxycholic } \\
\text { acid }\end{array}$ & $\mathrm{P}$ & Reptiles & $\begin{array}{l}\text { (Meyer and Zardoya, 2003; } \\
\text { Moschetta et al., 2005) }\end{array}$ \\
\hline Allocholic acid & $\mathrm{P}$ & Reptiles & (Vidal and Hedges, 2009) \\
\hline Allodeoxycholic acid & $\mathrm{S}$ & Rat, rabbit & $\begin{array}{l}\text { (Hofmann and Mosbach, 1964; } \\
\text { Kallner et al., 1967) }\end{array}$ \\
\hline Alloavicholic acid & $\mathrm{S}$ & Birds & (Hagey et al., 1994) \\
\hline
\end{tabular}

$\mathrm{P}=$ primary bile acid (formed in hepatocyte); $\mathrm{S}=$ secondary bile acid (formed in intestine by bacteria).

\section{Exogenous lipases and their mechanism of action}

Exogenous enzymes have great popularity among poultry and livestock industry (Beauchemin et al., 2003; Sarica et al., 2005). Avian liver health and function can be improved using exogenous enzymes; however, these aspects require further investigation (Zaefarian et al., 2019). Lipases are defined as triacylglycerol acyl hydrolases (EC 3.1.1.3) that are involved in the hydrolysis of fats and oils to yield glycerol and free fatty acids. As lipases are produced in the digestive tract to hydrolyze absorbed triglycerides, their synthesis might be activated by a hormone-sensitive regulation system in case of higher energy demands that ultimately initiates degradation of reserve triglycerides. Young animals with immature digestive capability for complete absorption of lipids could particularly benefit from dietary lipases (Pleiss et al., 1998; Fickers et al., 2011).

Lipases, like other enzymes, cannot tolerate high temperatures, extreme $\mathrm{pH}$, high ionic strength and organic solvents. Owing to these limitations like inactivation by gastric acidity, degradation by digestive tract proteases and physiological concentration of bile salts in the small intestine, most of the lipases cannot be applied to animal feed (Moreau et al., 1988; Zentler-Munro et al., 1992). Fungal lipase (Aspergillus niger) showed better stability, in terms of $\mathrm{pH}$ and temperature, when exposed to conditions associated with the glandular stomach compared to bacterial (Chromobacterium viscosum) and crude porcine lipase. The optimal $\mathrm{pH}$ for Aspergillus niger lipase and Chromobacterium viscosum lipase were 5 and 6-8, respectively. Exposure of lipases to $40^{\circ} \mathrm{C}$ and $\mathrm{pH} 7$ for $30 \mathrm{~min}$ has been shown to reduce the activity of all lipases except Aspergillus niger lipase. According to Wang et al. (2018), Yarrowia lipolytica (YL) lipase formulated with spayed drying with skimmed milk powder and starch, exhibited better stability under low $\mathrm{pH}$ with proteases and bile salts. The YL lipase supernatant displayed the best stability under low $\mathrm{pH}$ values compared to other lipases derived from different fungi (Rhizopus oryzae, Candida rugosa and Thermomyces lanuginosus). Therefore, in order to improve the stability and utilization, functional enzyme preparations with better efficacy spectrum are required. 
Lipases naturally catalyze the hydrolysis of triacylglycerols by attacking ester bonds. Mono- and diacylglycerols and free fatty acids are products of this enzymatic hydrolysis. They are also active on a broad range of substrates. In all cases, this reaction is carried out at the interface of a biphasic system (Pérez et al., 2019). This biphasic system originates from an immiscible organic phase, containing the hydrophobic substrate, in water. Lipases are also capable of expressing other related activities such as phospholipase, lysophospholipase, cholesterol esterase, cutinase, or amidase activities (Bora et al., 2013).

Lipase-mediated catalysis starts from formation of enzyme-substrate complex (Figure 3). It is accomplished in two steps: the first step is acylation, in which enzyme-substrate complex is formed through covalent bonding performed by proton transfer from aspartate and histidine to $\mathrm{OH}$ group of serine, which on activation attacks carbonyl group resulting in negative charge on the oxygen of carbonyl as an intermediate 'oxyanion'. This oxyanion is stabilized with hydrogen bonding with histidine where serine acts as a nucleophile and aspartate or glutamate as a catalytic acid residue that forms hydrogen bonds with amino acids present at active sites. In second step, deacylation is initiated by nucleophilic attack of a water molecule on enzyme-substrate complex at oxyanion site and fatty acid releases on leaving active enzyme freed for next reaction (Casas-Godoy et al., 2018).

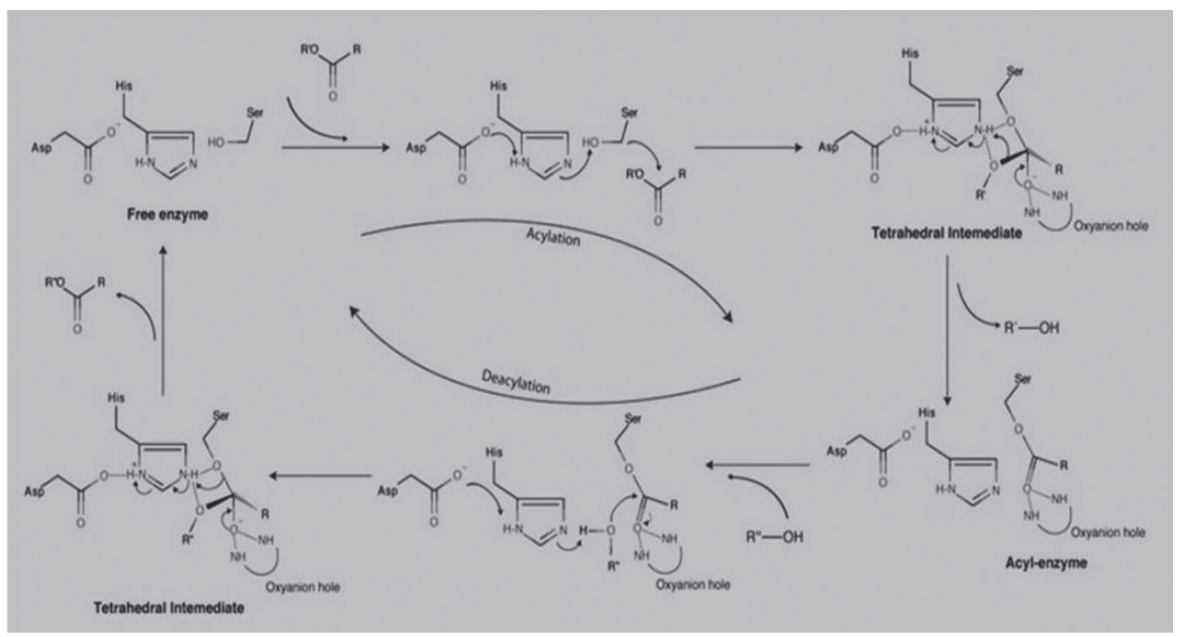

Figure 3. Catalytic mechanism of lipases (adapted from Casas-Godoy et al., 2018)

\section{Sources and application of lipases}

There are many sources of lipases available, and they are also extracted from various organisms such as animals, plants and microbial species in the food industry (Fallahi et al., 2018; Negi, 2019). Different sources of lipases have different properties and limitations. For example, pig pancreatic lipase is polluted by traces of trypsin which impart a bitter taste (Sharma and Kanwar, 2014). Other impurities include animal viruses and hormones. Therefore, due to the ease of production and abundance, frequently studied and industrially used lipases are obtained from mi- 
crobial sources. Moreover, compared to bacterial sources, lipases from generally recognized as safe (GRAS) yeast sources are widely accepted and used in several industries, including food processing (Johnson, 2013). Some of the major lipases used in industrial processes are listed in Table 3.

Table 3. Major lipases and their applications

\begin{tabular}{|c|c|c|c|}
\hline Type & Source & Application & References \\
\hline \multirow[t]{6}{*}{ Bacterial } & $\begin{array}{l}\text { Staphylococcus } \\
\text { haemolyticus }\end{array}$ & Food industry & (Jo et al., 2014) \\
\hline & $\begin{array}{l}\text { Pseudomonas } \\
\text { alcaligenes }\end{array}$ & Hydrolysis & $\begin{array}{l}\text { (Andualema and Gessesse, 2012; } \\
\text { Rios et al., 2018) }\end{array}$ \\
\hline & Serratia marcescens & Hydrolysis & (García-Silvera et al., 2018) \\
\hline & $\begin{array}{l}\text { Bacillus } \\
\text { licheniformis }\end{array}$ & Oil and fat industry & (Rashid et al., 2013) \\
\hline & $\begin{array}{l}\text { Pseudomonas } \\
\text { mendocina }\end{array}$ & $\begin{array}{l}\text { Hydrolysis } \\
\text { Detergents }\end{array}$ & (Zhang et al., 2019) \\
\hline & $\begin{array}{l}\text { Chromobacterium } \\
\text { viscosum }\end{array}$ & Lipolysis organic synthesis & $\begin{array}{l}\text { (Lang et al., 1996; Bajaj et al., } \\
\text { 2010) }\end{array}$ \\
\hline \multirow[t]{8}{*}{ Fungal } & Yarrowia lipolytica & Hydrolysis, lipid absorption & $\begin{array}{l}\text { (Brígida et al., 2014; Wang et al., } \\
\text { 2018) }\end{array}$ \\
\hline & Aspergillus oryzae & Lipolysis oleochemistry & $\begin{array}{l}\text { (Sánchez et al., 2002; Abe et al., } \\
\text { 2006) }\end{array}$ \\
\hline & Rhizomucor miehei & $\begin{array}{l}\text { Flavour and fragrance } \\
\text { detergents }\end{array}$ & (Chang et al., 2003) \\
\hline & Pecillium chrysogenum & Waste cooking oil transformation & (Kumar et al., 2012) \\
\hline & Rhizopus chinensis & Flavoured milk products & (Xiao et al., 2015) \\
\hline & Aspergillus niger & Feed, aquaculture supplement & (Collar et al., 2000) \\
\hline & $\begin{array}{l}\text { Thermomyces } \\
\text { lanuginosus }\end{array}$ & Transesterification & $\begin{array}{l}\text { (Fernandez-Lafuente, 2010; } \\
\text { Dantas et al., 2019) }\end{array}$ \\
\hline & $\begin{array}{l}\text { Geotrichum } \\
\text { candidum }\end{array}$ & Hydrolytic kinetic resolution & $\begin{array}{l}\text { (Brabcová et al., 2013; de Morais } \\
\text { Júnior et al., 2018) }\end{array}$ \\
\hline \multirow[t]{3}{*}{ Yeast } & Williopsis californica & Food & (Negi, 2019) \\
\hline & Candida antarctica & Food, pharmaceuticals & $\begin{array}{l}\text { (Kapoor and Gupta, 2012; } \\
\text { Primožič et al., 2016) }\end{array}$ \\
\hline & Candida rugosa & $\begin{array}{l}\text { Food processing, quick drying } \\
\text { oils }\end{array}$ & (Dhake et al., 2013) \\
\hline \multirow[t]{3}{*}{ Animal } & Pig pancreatic lipase & Hydrolysis, transesterification & $\begin{array}{l}\text { (Caballero et al., 2009; Zheng et } \\
\text { al., 2014) }\end{array}$ \\
\hline & Calf, kid and lamb & Hydrolysis & $\begin{array}{l}\text { (Villeneuve et al., 1996; } \\
\text { O’Connor et al., 2001) }\end{array}$ \\
\hline & Chicken & Hydrolysis & (Borrelli and Trono, 2015) \\
\hline \multirow[t]{3}{*}{ Plant } & Almond & Oil & (Huang et al., 2017) \\
\hline & Coconut & Coconut oil & (Zin et al., 2017) \\
\hline & Castor beans & Vegetable oils & (Salaberría et al., 2017) \\
\hline
\end{tabular}


Some techniques have been developed to obtain higher conversions for highly specific enzymes for each application, improving the possibility of industrial applications of lipases (Soccol and Vandenberghe, 2003; Franken et al., 2010). Candida rugosa lipases have great significance for their diverse biotechnological potentials (Pandey et al., 1999). Existence of C. rugosa lipase isoforms has been reported by several authors (Jaeger et al., 1994; Benjamin and Pandey, 1998). Rhizopus species is mainly divided into three groups, Rhizopus oryzae, Rhizopus microsporus, and Rhizopus stolonifer which generally produce $R$. oryzae lipase, Rhizopus delemar lipase, and Rhizopus javanicus lipase, respectively (Minning et al., 1998). Lipase gene from $R$. stolonifer possesses $84 \%$ sequence homology (amino acid) with $R$. oryzae lipase. However, there is no report on molecular characterization of lipase from $R$. microspores (Yu et al., 2009).

The lipase from YL is an ideal candidate for enzyme replacement therapy due to its unique biochemical properties: It shows the highest activity at low $\mathrm{pH}$ values and is not repressed by bile salts. The YL belongs to the same gene family as Thermomyces lanuginosus lipase, a well-known lipase with many applications in the field of detergents and biotechnological processes (Aloulou et al., 2007). Although these two lipases show a high sequence identity of $30.3 \%$, they have relatively different biochemical properties.

\section{Intestinal digestion and absorption of fat}

Majority of fats emulsified by pancreas and bile salt-stimulated lipases are digested in the lumen of small intestine (Liao et al., 1984; Hamosh et al., 1989). Fat globules made up of multiple lipids, including triglycerides, are emulsified by bile salts in intestine (Figure 4). The emulsion droplets are hydrolyzed by lipases releasing free fatty acids and monoglycerides. Small micelles absorbed by the intestinal epithelium, form free fatty acids and monoglycerides with bile salts. After re-esterification of free fatty acids and monoglycerides in intestinal cells and subsequent packing into chylomicrons, they are secreted into the lacteal and lymphatic circulation of the intestine.

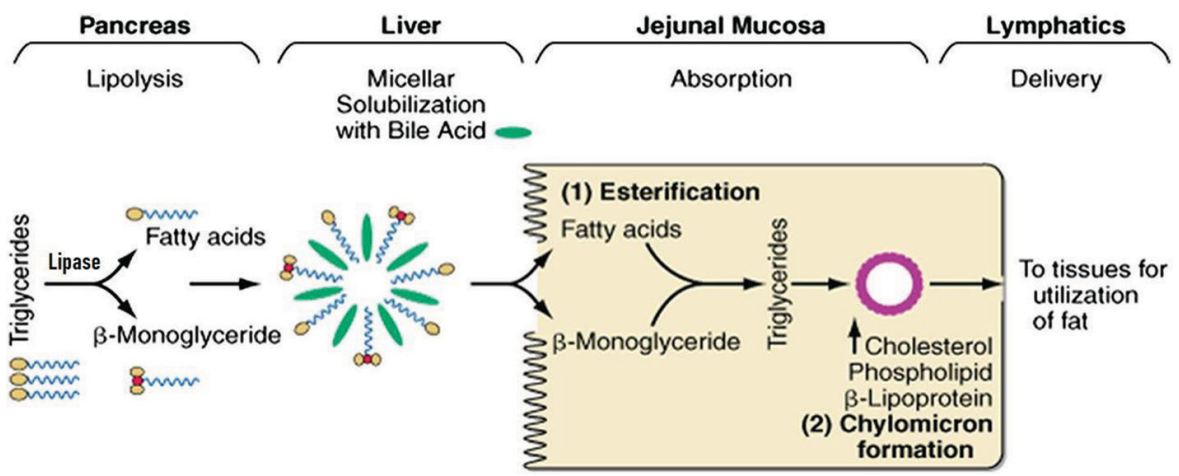

Figure 4. Mechanism of action of both bile acids and lipases (adapted from Martin, 2015) 


\section{Effect of dietary bile acids on feed intake and FCR}

Response to dietary bile acids at an earlier age in broiler was highly variable in different studies (Table 4$)$. In many studies better FCR $(\mathrm{P}<0.05)$ was observed in response to bile acid supplementation at same feed intake during both starter and finisher phases (Atteh and Leeson, 1985; Maisonnier et al., 2003; Ge et al., 2018). These findings provide evidence that broilers have a limited amount of endogenous bile during an early age, which can be overcome by using dietary bile acids. However, in some studies it has been reported that dietary bile acid improved FCR only during the finisher phase (Alzawqari et al., 2011; Lai et al., $2018 \mathrm{a}, \mathrm{b}$ ). On the contrary, a decrease in feed intake has been observed in response to inclusion of chenodeoxycholic acid in broiler diet (Polin et al., 1980; Hemati Matin et al., 2016; Piekarski et al., 2016). Reduction in feed intake, firstly might be due to synergistic effects of some components of natural bile acids that are not present in synthetic or purified bile acids, and secondly due to low plasma glucose level. The most abundant bile acids in swine include chenodeoxycholic acid and $\alpha$-hyodeoxycholic acid, which is exclusive to swine, while chenodeoxycholic acid and cholic acid predominate in broiler biliary acids. It appears that chenodeoxycholic acid had little effect on performance in pigs, while it can decrease feed intake of broiler. A recent study has shown that exogenous emulsifiers/salts (phosphatidyl choline, lysophosphatidyl choline and polyethylene glycol ricinoleate) have potential to improve FCR of broilers fed low energy diet ( $<50 \mathrm{kcal} / \mathrm{kg} \mathrm{ME}$ ) compared to the basal diet (Saleh et al., 2020). Variable results about the effect of bile acids may be due to different source of bile acids feed ingredients used in broiler diets.

\section{Effect of dietary lipase on feed intake and FCR}

Dietary lipases are claimed to be effective in improving feed efficiency in broilers (Nagargoje et al., 2016; Hu et al., 2018). Significant improvement in FCR has been reported in broilers with no effect on feed intake in response to supplementation of different levels of lipase enzyme (Al-Marzooqi and Leeson, 2000; Wang et al., 2018). These studies revealed that chicken might have a limited amount of endogenous pancreatic lipase during an early age, which can be augmented by using dietary lipase. However, in some studies addition of lipase in broiler diet has also shown no significant changes in feed intake and FCR (Polin et al., 1980; Meng et al., 2004). No effect of inclusion of dietary lipase on the performance of chicken suggests that insufficiency of pancreatic lipase production may not contribute to the lower-fat digestibility of tallow-containing diets. On the contrary, Al-Marzooqi and Leeson (1999) have reported that addition of lipase to broiler diet resulted in significant depression in feed intake and FCR (Table 5).

\section{Effect of dietary bile acids on growth rate and body weight}

Improvement in body weight (BW) gain in broilers in response to supplementation of emulsifiers in their diet has been reported in many studies (Table 4). Addition of bile acids to diets has exhibited growth-promoting effect on broilers during first 21 days of rearing period (Maisonnier et al., 2003; Parsaie et al., 2007; Ge et al., 2018). However, during the finisher phase (22-42 days) ADG remained unaffected. 
Similarly, Atteh and Leeson (1985) reported that supplementary chenodeoxycholic acid and cholic acid had higher $(\mathrm{P}<0.05)$ ADG $(2.67 \mathrm{vs} 2.51 \mathrm{~g})$ and $\mathrm{BW}$ gain $(2001$ g vs $1937 \mathrm{~g}$ ) in broilers. They suggested that improved performance of birds was mainly due to enhanced dietary metabolizable energy and nutrients (especially fat) digestibility. On the other hand, some researchers reported that supplementation of different bile acids in broiler diets exhibited no effect on BW gain during first 21 days of rearing (Lai et al., 2018 a, b). However, during the finisher phase (22-42 days) a significant increase was observed in ADG. Bile acids used in this study were composed of $8 \%$ hyocholic acid, $70.67 \%$ hyodeoxycholic acid and $19.1 \%$ chenodeoxycholic acid. Alzawqari et al. (2011) observed that supplementation of $0.25 \%$ and $0.50 \%$ desiccated ox bile in broiler diet exhibited a significant effect on BW gain only during 42 days of the rearing period. Significant increase in BW gain of birds fed bile might be due to the higher availability of energy derived from enhanced fat absorption. However, no possible explanation of non-significant effects on BW during the first 21 days was given. On the contrary, Piekarski et al. (2016) reported that supplementing $0.01 \%$ and $0.5 \%$ bile acids (chenodeoxycholic acid) resulted in a decrease in body weight by $3-6 \%$ and $7-11 \%$ respectively, as compared to control group. These changes were accompanied by a significant decrease in plasma glucose levels. Reduced growth performance (decrease in feed intake and BW) in chicken might have been due to modulation of feeding-related hypothalamic neuropeptides and hepatic lipogenesis-related genes.

Table 4. Effect of bile acids on the performance of broiler

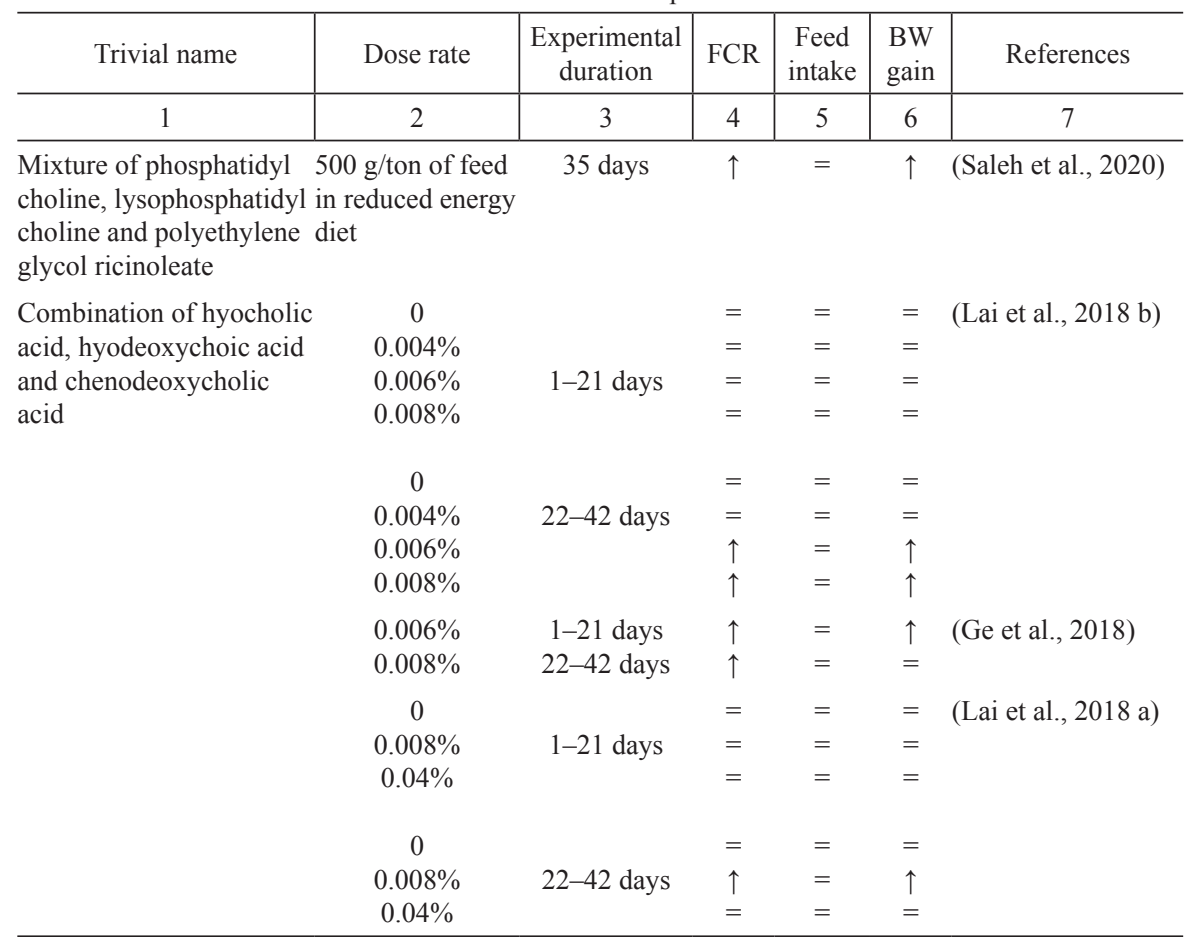


Table 4 - contd.

\begin{tabular}{|c|c|c|c|c|c|c|}
\hline 1 & 2 & 3 & 4 & 5 & 6 & 7 \\
\hline Chenodeoxycholic acid & $\begin{array}{l}0.01 \% \\
0.5 \%\end{array}$ & 21 days & $\begin{array}{l}= \\
=\end{array}$ & $\begin{array}{l}\downarrow \\
\downarrow\end{array}$ & $\begin{array}{l}\downarrow \\
\downarrow\end{array}$ & $\begin{array}{l}\text { (Piekarski et al., } \\
\text { 2016) }\end{array}$ \\
\hline \multirow[t]{2}{*}{ Desiccated ox bile } & $\begin{array}{c}0 \\
0.25 \% \\
0.50 \%\end{array}$ & $1-21$ days & $\begin{array}{l}= \\
= \\
=\end{array}$ & $\begin{array}{l}= \\
= \\
=\end{array}$ & $\begin{array}{l}= \\
= \\
=\end{array}$ & $\begin{array}{l}\text { (Alzawqari et al., } \\
\text { 2011) }\end{array}$ \\
\hline & $\begin{array}{c}0 \\
0.25 \% \\
0.50 \%\end{array}$ & $22-42$ days & $\begin{array}{l}= \\
\uparrow \\
\uparrow\end{array}$ & $\begin{array}{l}= \\
= \\
=\end{array}$ & $\begin{array}{l}= \\
\uparrow \\
\uparrow\end{array}$ & \\
\hline $\begin{array}{l}\text { Bile salts (sodium } \\
\text { taurocholate) }\end{array}$ & $0.3 \%$ & $7-21$ days & $\uparrow$ & $=$ & $\uparrow$ & $\begin{array}{l}\text { (Maisonnier et al., } \\
\text { 2003) }\end{array}$ \\
\hline \multirow[t]{2}{*}{ Cholic acid } & $0.05 \%$ & $1-18$ days & $=$ & $\uparrow$ & $\uparrow$ & (Parsaie et al., 2007) \\
\hline & $0.2 \%$ & $1-56$ days & $\uparrow$ & $=$ & $\uparrow$ & $\begin{array}{l}\text { (Atteh and Leeson, } \\
\text { 1985) }\end{array}$ \\
\hline $\begin{array}{l}\text { Cholic acid and } \\
\text { chenodeoxycholic acid }\end{array}$ & $0.04 \%$ & 1-7 days & $\uparrow$ & $\downarrow$ & $\uparrow$ & (Polin et al., 1980) \\
\hline
\end{tabular}

$\uparrow=$ improve; $\downarrow=$ decrease/deteriorate; = no effect.

Table 5. Effect of lipase on the performance of broiler

\begin{tabular}{l|c|c|c|c|c|c}
\hline \multicolumn{1}{c|}{ Trivial name } & Dose rate & $\begin{array}{c}\text { Experimental } \\
\text { duration }\end{array}$ & FCR & $\begin{array}{c}\text { Feed } \\
\text { intake }\end{array}$ & $\begin{array}{c}\text { BW } \\
\text { gain }\end{array}$ & References \\
\hline Yarrowia lipolytica & 0 & 42 days & $\uparrow$ & $=$ & $=$ & (Wang et al., 2018) \\
lipase & $4 \mathrm{U} / \mathrm{g}$ & & & & & \\
& $6 \mathrm{U} / \mathrm{g}$ & & & & & \\
Microbial lipase & $0.015 \%$ & $1-14$ days & $\uparrow$ & $=$ & $\uparrow$ & (Hu et al., 2018) \\
& $0.03 \%$ & & & & & \\
Lipase & $100000 \mathrm{IU} /$ ton & 42 days & $\uparrow$ & $=$ & $=$ & (Nagargoje et al., 2016) \\
& of feed & & & & & \\
Lipase (pancreatic) & $0.02 \%$ & $1-18$ days & $=$ & $=$ & $=$ & (Meng et al., 2004) \\
Lipase (pancreatic) & $0 \%$ & $1-21$ days & $\uparrow$ & $\downarrow$ & $\downarrow$ & (Al-Marzooqi and Leeson, 2000) \\
& $0.375 \%$ & & & & & \\
& $0.750 \%$ & & & & & \\
& $1.125 \%$ & & & & & \\
Lipase (pancreatic) & $0.714 \%$ & $1-12$ days & $\downarrow$ & $\downarrow$ & $\downarrow$ & (Al-Marzooqi and Leeson, 1999) \\
Lipase & $0 \%$ & $1-21$ days & $=$ & $=$ & $=$ & (Polin et al., 1980) \\
& $0.01 \%$ & & & & & \\
& $0.1 \%$ & & & & & \\
&
\end{tabular}

$\uparrow=$ improve; $\downarrow=$ decrease/deteriorate; = no effect.

\section{Effect of dietary lipase on growth rate and body weight}

Lack of response on growth performance to exogenous lipase enzyme has been reported in many studies in broilers during a period of 42 days (Polin et al., 1980; Wang et al., 2018). However, it does not necessarily mean that enzyme products fail to work on their specific substrates (Cowieson and Adeola, 2005). Meng et al. (2004) reported that supplementation of $0.02 \%$ lipase caused no difference in ADG and $\mathrm{BW}$ gain during a period of 18 days (Table 5). On the other hand, $\mathrm{Hu}$ et al. 
(2018) reported that providing a reduced energy diet had decreased $(\mathrm{P}<0.05) \mathrm{BW}$ gain compared to basal diet during first 14 days of rearing, though reduced BW gain was compensated with supplementation of $0.015 \%$ and $0.03 \%$ lipase in reduced energy diets. Therefore, due to the overwhelming complexity of full function of coenzyme and other compounds, further research is required to confirm the effects of feed enzyme preparations. In previous studies (Al-Marzooqi and Leeson, 1999, 2000), adverse effects of enzymes on growth performance of the broiler have been reported. The reason for reduced performance may be due to contamination of lipase enzyme with cholecystokinin, which influences satiety signals ultimately affecting feed intake (Antin et al., 1975; Savory and Gentle, 1980).

\section{Effect of dietary bile acids on carcass characteristics}

Bile acids can improve absorption of dietary lipids which are not stored in abdominal fat (Table 6). According to Lai et al. (2018 b) and Ge et al. (2018), dietary bile acids possess significant potential to improve dressing percentage and carcass characteristics in broiler partly through a reduction of abdominal fat. The abdominal fat pad is a reliable indicator for judging total body fat contents owing to its direct association with total body fat contents in avian species (Becker et al., 1979; Thomas et al., 1983). Supplementation of bile acids has also shown desirable effects on breast muscles index. However, liver and thymus indices were reduced by bile acids (Ge et al., 2018). Parsaie et al. (2007) reported a significant decrease in liver weight due to dietary cholic acid. Liver is a principal site for detoxification and bile production, and its size is directly associated with functional load.

\section{Effect of dietary lipase on carcass characteristics}

Dietary lipase enzyme failed to bring change in abdominal fat percentage of broilers fed tallow based diet (Nagargoje et al., 2016; Hu et al., 2018) (Table 7). This effect may be attributed to dietary fat and fatty acid composition of the diets. Sanz et al. (2000) reported that broilers fed diets containing unsaturated fat exhibited less abdominal fat and fatty acid synthesis than those fed diets containing saturated fat. Increasing level of lipase enzyme resulted in higher liver weight $(\mathrm{P}<0.05)$ at 21 st day of age (Al-Marzooqi and Leeson, 2000). Improvement in liver weight might be due to increased metabolic activity associated with lipid utilization.

\section{Effect of dietary bile acids on fat digestibility}

Energy-yielding potential of fat is markedly influenced by its chemical structure (Freeman, 1984; Krogdahl, 1985). Fatty acids composition, their chain length and saturation degree of the carbon chain all impact digestion and absorption of fats. Degree of saturation of fatty acid has a major influence on the AME of fats (Wiseman et al., 1991). Animal fats containing high amounts of long-chain saturated fatty acids (palmitic and stearic acids) are poorly digested and absorbed by poultry (Danicke, 2001; Leeson and Summers, 2001). Saturated fatty acids require bile salts to emulsify them and to form micelles before digestion. Garrett and Young (1975) reported that solubilization and absorption of saturated fatty acids are more negatively affected by the absence of bile salts than those of unsaturated fatty acids. Both pal- 
mitic and stearic acids are non-polar and cannot spontaneously form mixed micelles. They require the presence of conjugated bile salts and unsaturated fatty acids to form mixed micelles. On the other hand, vegetable oils contain high concentrations of unsaturated fatty acids that are easily emulsified and better digested than tallow (Sklan, 1979). Usually, high energy diets exhibit poor digestibility of fat, due to lower bile acids and lipase synthesis in poultry birds. Supplementation of bile acids $(2.5 \mathrm{~g} / \mathrm{kg})$ in broiler diet significantly improved apparent ileal digestibility of fat (Atteh and Leeson, 1985; Alzawqari et al., 2011; Hemati Matin et al., 2016; Lammasak et al., 2018). Similarly, Maisonnier et al. (2003) reported that supplementation of $0.3 \%$ bile salts (sodium taurocholate) improved $(\mathrm{P}<0.05)$ lipid digestibility $(89.4 \%$ vs $81.4 \%$ ), but combination of bile salts with $0.5 \%$ guar gum had negative effect on lipid digestibility ( $85.7 \%$ vs $89.4 \%$ ). The negative effect of guar gum on lipid digestibility was mediated mainly by higher viscosity hindering absorption of bile salts and fatty acids, leading to reduced intestinal pool size of bile salts and reduced lipid digestibility (Table 6).

\section{Effect of dietary lipase on fat digestibility}

Studies evaluating supplemental lipases are scanty and in general, have not to date yielded similar outcomes (Table 7). For example, Meng et al. (2004) found no effect of lipase addition on fat digestibility or AME in young broilers. Researchers suggested that insufficiency of pancreatic lipase synthesis may not be a significant factor contributing to incomplete fat digestion in young birds. On the contrary, fat digestibility was significantly improved due to supplementation of lipase in broiler diets (Polin et al., 1980; Brenes et al., 2008; Hu et al., 2018). On the other hand, AlMarzooqi and Leeson (1999) reported that supplemental lipase in the diet was effective in increasing animal fat digestibility, although it is suspected that reduced feed intake may be due to contaminants like cholecystokinin hormone.

\section{Effect of dietary bile acids on serum lipid metabolites}

Concentrations of lipoproteins and plasma lipids are considered diagnostic markers in the metabolism of lipids. Synthesis of adipose tissue and fat deposition in poultry is dependent on available serum triglycerides (TG). Most fatty acids are synthesized into the liver and carried in adipose tissue as triglycerides via LDL or chylomicron (Hermier, 1997). In contrast, HDL promotes uptake and transport of cholesterol to liver for catabolism from peripheral tissues (Miller and Miller, 1975). It has been reported that bile acids possess hypocholesterolemic properties (Ge et al., 2018). Recently, Saleh et al. (2020) showed that plasma total cholesterol, HDL-cholesterol, total protein and globulin contents were lower in the low energy diets $(<50$ $\mathrm{Kcal} / \mathrm{kg}$ ). However, their concentration seemed to be increased with supplementation of exogenous emulsifier/salts. Hemati Matin et al. (2016) reported birds fed a diet supplemented with bile acids resulted in a lower serum concentration of TG and LDL-C, whereas serum concentrations of HDL-C and total cholesterol (TG) were unaffected. Supplementation of bile acids failed to change serum TG, total cholesterol, HDL-C and LDL-C content (Alzawqari et al., 2011; Lai et al., 2018 a). It might be due to failure of cholesterol transportation from peripheral tissues to the liver. 


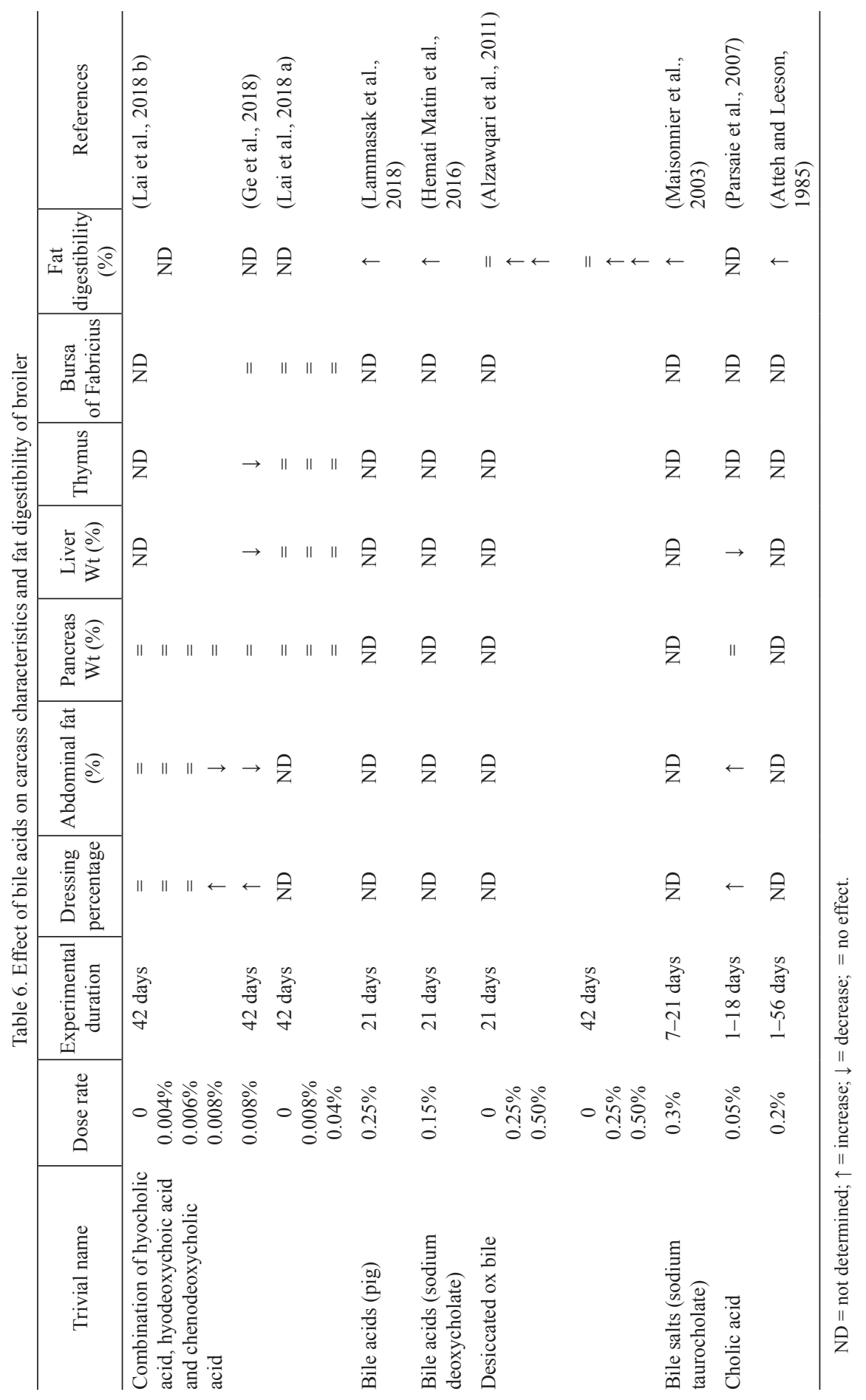




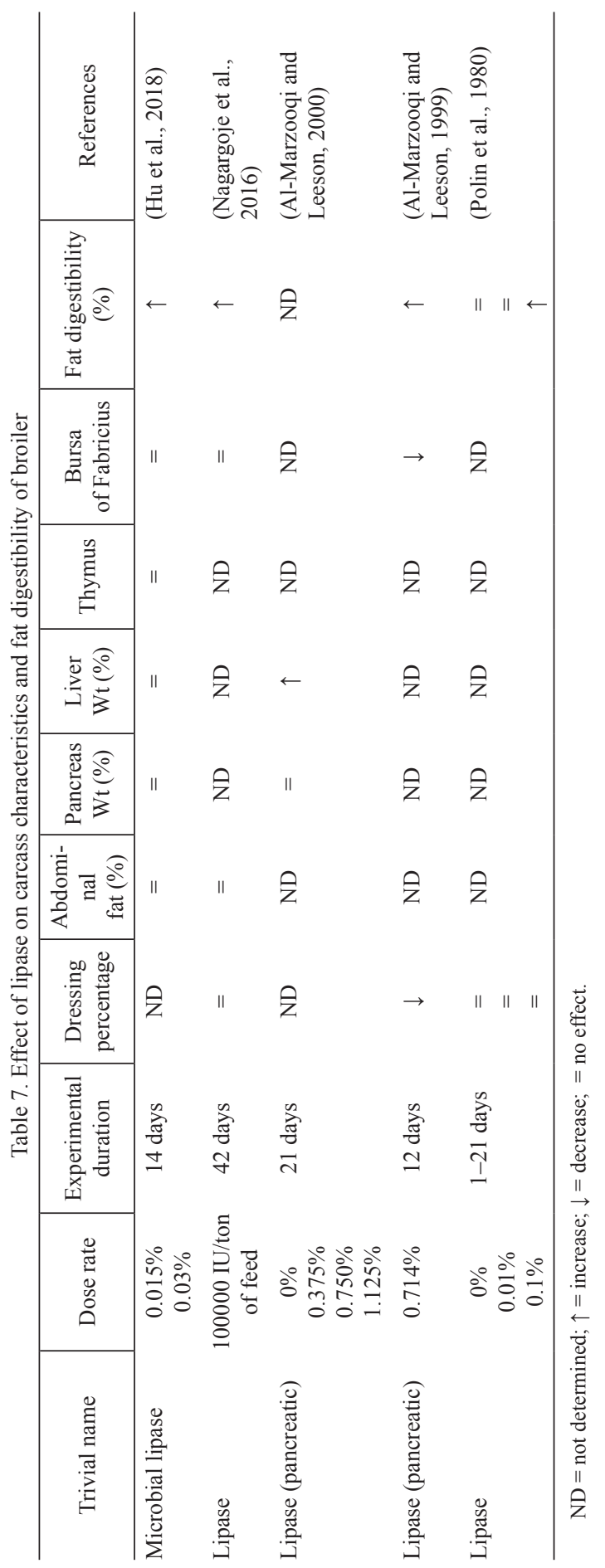




\section{Effect of dietary lipase on serum lipid metabolites}

Studies on the effect of supplemental lipases on serum lipid metabolites are limited. Triglycerides are fatty acid trimesters of glycerol that are derived from food as well as produced by the animal body. They were secreted from the liver into the blood by TG-rich lipoproteins. Brenes et al. (2008) reported that dietary lipase has hypocholesterolemic activity in broilers. In a further study, dietary lipase significantly reduced total, TG and LDL-C, whereas HDL-C remained unaffected ( $\mathrm{Hu}$ et al., 2018). It has been suggested that faster rates of absorption and metabolism of ingested fat may be the reason for lower serum TGs in broiler fed lipase. However, further studies are warranted to reveal the mechanism affecting lipase in serum profiles.

\section{Effect of dietary bile acids on enzyme activities}

Intestinal lipase activity can be an indicator of lipid utilization in animals. Hormone-sensitive lipase (HSL) is an intracellular neutral lipase and is activated when the body needs energy derived from lipid mobilization. It is the rate-limiting enzyme in the degradation of triacylglycerol to diacylglycerol and free fatty acids (Duncan et al., 2007). The activity of HSL was decreased in $42 \mathrm{~d}$ old broiler fed 60 and $80 \mathrm{mg} /$ $\mathrm{kg}$ bile acids indicating that bile acids could improve the efficiency of fat digestion and absorption, leading to reduce requirements of dietary fat. Energy density of diets is also associated with total endogenous lipase activity in the gut. It has been reported that high-energy diets decreased $(\mathrm{P}<0.05)$ hepatic LPL activity at $42 \mathrm{~d}$, which was increased by supplemented bile acids (Ge et al., 2018). Different dietary fibres present in poultry diets have been also shown to interact with supplementation of bile acids in birds. Supplementation of $0.15 \%$ bile acids in the diet decreased pancreatic lipase activity (PLA) (Hemati Matin et al., 2016). Similarly, Knarreborg et al. (2003) reported that lipase activity of proximal part of the small intestine was low due to increased level of unconjugated bile acids (sodium deoxycholate) in broilers.

\section{Effect of dietary lipase on enzyme activities}

Reports on the effect of lipase on enzyme activity in birds are limited. According to Brenes et al. (2008) addition of lipase enzyme improved pancreatic amylase activity and PLA. Ultimately, these activities resulted in improved performance of birds. $\mathrm{Hu}$ et al. (2018) reported that supplementation of $0.03 \%$ lipase enzyme had positive $(\mathrm{P}<0.05)$ effects on PLA. However, no differences were found in digestive enzyme activities with enzyme supplementation on d 28 of age. Researchers suggested age as a possible reason for no effect of lipase on digestive enzyme activities except pancreas lipase, because the digestive enzyme activities may be less affected by dietary manipulation in adult birds than in young birds (Liu and Kim, 2017). However, further investigations are required to provide mechanistic insights into this aspect.

\section{Effect of dietary bile acids on intestinal morphology}

Dietary bile acids have potential to improve intestinal morphology in terms of villus height, crypt depth and villus-to-crypt ratio of jejunum (Alzawqari et al., 2011). In contrast, Parsaie et al. (2007) reported that $0.05 \%$ dietary cholic acid decreased $(\mathrm{P}<0.05)$ height of duodenal villi $(0.968 \mathrm{~mm}$ vs $1.086 \mathrm{~mm})$ and depth of ileal 
villi compared to control. Villi are considered as the most important sites for nutrient absorption. Longer villi provide more surface area and are capable of higher absorption of available nutrients (Caspary, 1992).

\section{Effect of dietary lipase on intestinal morphology}

Reports on the effect of lipase on enzyme activity in birds are minimal. Hu et al. (2018) reported that supplementation of $0.03 \%$ lipase in low energy diets increased $(\mathrm{P}<0.05)$ villus height $(911$ vs $778 \mu \mathrm{m})$ and the ratio of villus height and crypt depth (8.59 vs 6.82). It indicated an increased digestive and absorptive capacity of small intestine in response to greater flow of nutrients for optimal growth of broilers. Additionally, this may also be responsible for improved nutrient digestibility. Villus height was associated with absorption capacity of enterocytes, and short villi may decrease surface area for nutrient absorption (Parsaie et al., 2007). Recently, Bansal et al. (2020) showed that dietary deoxycholic acid $(1.5 \mathrm{~g} / \mathrm{kg})$ has potential to reduce $C$. perfringens luminal colonization in birds infected with E. maxima and $C$. perfringens. These infected birds had short villi, crypt hyperplasia and immune cell infiltration in the ileum; however, supplementation of deoxycholic acid effectively alleviated the ileal inflammation.

\section{Effect of dietary bile acids on meat quality}

Meat color is considered as one of the most important characteristics for customers and is often used to determine the economic value of food (Mugler and Cunningham, 1972). No report is available in literature regarding the effect of bile acids on meat quality in broilers. However, studies involving other emulsifiers are available, and a majority of them reported non-significant effects of emulsifier supplementation on meat quality parameters (Zhao and Kim, 2017; Bontempo et al., 2018; Upadhaya et al., 2018).

\section{Effect of dietary lipase on meat quality}

Limited reports are available regarding the effect of lipase on meat quality in broilers. Recently, Hu et al. (2018) reported that supplementation of lipase enzyme did not affect $\mathrm{pH}$ value, color (redness, yellowness and lightness) of breast muscle, water holding capacity and drip loss in broilers. Similarly, Nagargoje et al. (2016) reported that supplementation of lipase enzyme exhibited no effect on $\mathrm{pH}$ of breast and thigh muscles.

\section{Future implications}

Accelerated growth rate and body weight gain of broilers require highly nutritious and energy-dense diets to match body requirementd and energy balance. This scenario demands to look for nutrients that can increase energy density of diets without compromising feed intake and feed costs. Dietary fats contain the highest caloric value of all other nutrients and are ideal to meet energy requirements of high performing birds. Nevertheless, the issue with dietary fat is that their digestion is a complex process as it involves many steps, including breakdown of fat droplet, emulsification, lipolysis and micelle formation. 
Moreover, emulsification of fat requires endogenous bile acids secreted by liver and pancreatic lipase, which have limited activity in birds, especially at a younger age. Addition of fats in poultry diets to make high-density diets will further require the addition of exogenous bile acids and lipase for better emulsification and utilization of fats. In this case, these two additives for dietary fat utilization are crucial and an understanding of their role in efficient digestion and absorption of fats is warranted. A better understanding of both is inevitable, especially in the future scenario of increasing feed costs and competition for developing economical and energy efficient diets. Although bile acids and their derivatives appear to have positive effects on fat digestion and birds performance, it must be noted that the extent of improvement would be different for different bile salts. In the past they were expensive, but presently their use in poultry diets is cost-effective and is of practical interest. However, further investigations are required to critically evaluate the potential of bile acids and lipase enzyme in broiler nutrition with a specific focus on improving intestinal morphology, gut microbiome and meat quality.

Recent developments in omics technologies have made it possible to investigate effects of nutrients on gut microbiome and transcriptome, so it will be interesting to explore effects of these additives on metabolism, gut microbiota and ileal absorption capacity. Moreover, bile acids as signalling molecules have become a topic of increasing interest in mammals as they play a role not only as intestinal detergent molecules but also as metabolic regulators and molecular signatures that affect body lipid, glucose and energy metabolism (Thomas et al., 2008; Prawitt et al., 2011). Such effects are presently unknown in avian species. Furthermore, modulation of hypothalamic neuropeptides and genes associated with hepatic lipogenesis has opened up new pathways for further study to decipher the underlying downstream processes in chicken. Therefore, the effects of bile acid and lipase on global gene expression profiles and epigenetic signalling will provide new insights into the interaction of these compounds with nutrient's absorption, metabolism and cellular uptake.

\section{Conclusions}

Literature survey provided convincing evidence that dietary supplementation of bile acids and lipase improves in broiler performance owing to increased fat digestibility due to improved pancreatic lipase activity. However, due to the wide variety of available products, effective dosage of both supplements showed substantial variation in different studies. Studies have evaluated wide supplemental range of bile acids $(0.004 \%$ to $0.25 \%)$ and lipases $(0.01 \%$ to $0.1 \%)$ in broiler diets for improvement of fat digestibility and performance. However, combinations of different bile acids have shown more potential to improve feed efficiency even at low $(0.008 \%)$ levels as compared to any individual bile acid. Likewise, lipases at a lower level of $0.03 \%$ have exhibited more promising potential to improve feed efficiency. Recent studies have shown that bile acids can effectively enhance digestive enzymatic activity and absorption capacity through improving intestinal morphology. These findings, along with a scope of bile acids as signalling molecule have opened a new horizon for future implications of bile acids in the poultry industry. Dietary supplementation of bile acids and lipases to enhance the efficiency of nutrient utilization through 
modulation of intestinal morphology can have many far-reaching effects on performance and health of birds. However, further investigations are required to explore the potential interaction of bile acids and lipases with gut microbiome and immunity.

\section{References}

A b e K., G o m i K., H a s e g a w a F., M a ch id a M. (2006). Impact of Aspergillus oryzae genomics on industrial production of metabolites. Mycopathologia, 162: 143-153.

A budabos A. (2014). Effect of fat source, energy level and enzyme supplementation and their interactions on broiler performance. S. Afr. J. Anim. Sci., 44: 280-287.

A g e 11 o n J.B. (2008). Metabolism and function of bile acids. In: Biochemistry of lipids, lipoproteins and membranes, Vance D.E., Vance J.E. (eds). Elsevier, New York, pp. 423-440.

A guilar Y.M., B e cerra J.C., B ert ot R.R., Peláe z J.C., Li u G., Hurtado C.B. (2013). Growth performance, carcass traits and lipid profile of broiler chicks fed with an exogenous emulsifier and increasing levels of energy provided by palm oil. J. Food Agri. Environ., 11: 629-633.

A l- M a r z o o qi W., L e e s on S. (1999). Evaluation of dietary supplements of lipase, detergent, and crude porcine pancreas on fat utilization by young broiler chicks. Poultry Sci., 78: 1561-1566.

A 1 - M a r z o o q i W., L e e s o n S. (2000). Effect of dietary lipase enzyme on gut morphology, gastric motility, and long-term performance of broiler chicks. Poultry Sci., 79: 956-960.

Ali S.F., Chao W., Xiaoli W., Jintian H., Mingfa W., El-Hack M.E.A., Lili Z., Xi ang Z., Tian W. (2017). Growth, serum biochemical indices, antioxidant status and meat quality of broiler chickens fed diet supplemented with sodium stearoyl-2 lactylate. Pak. Vet. J., 37: $445-449$.

Aloulou A., Rodriguez J.A., Puccinelli D., Mouz N., Leclaire J., Leblond Y., C a r r i èr e F. (2007). Purification and biochemical characterization of the LIP2 lipase from Yarrowia lipolytica. Biochimic. Biophys. Acta -Mol. Cell Biol. Lipids, 1771: 228-237.

A 1 zaw q a ri M., M ogh add a m H.N., K erm an shah i H., R a j i A.R. (2011). The effect of desiccated ox bile supplementation on performance, fat digestibility, gut morphology and blood chemistry of broiler chickens fed tallow diets. J. Appl. Anim. Res., 39: 169-174.

A nd er s on I.G., B a n is ter K.E., H a s l e w o o d G.A., C ho D., To e k e s L. (1980). Bile salts of fishes collected on the Zaïre River Expedition (1974-1975): their chemical nature and its possible significance. Zool. J. Linnean Soc., 68: 41-51.

A nd u a le ma B., Ge s se s se A. (2012). Microbial lipases and their industrial applications. Biotechnology, 11: 100-118.

Antin J., Gibbs J., Holt J., Young R.C., S m ith G.P. (1975). Cholecystokinin elicits the complete behavioral sequence of satiety in rats. J. Comp. Physiol. Psychol., 89: 784.

A t $t$ e h J., L e e s o n S. (1985). Influence of age, dietary cholic acid, and calcium levels on performance, utilization of free fatty acids, and bone mineralization in broilers. Poultry Sci., 64: 1959-1971.

A z m a n M., C i f t c i M. (2004). Effects of replacing dietary fat with lecithin on broiler chicken zootechnical performance. Rev. Med. Vet., 155: 445-448.

B a i ã o N.C., L a r a L. (2005). Oil and fat in broiler nutrition. Braz. J. Poult. Sci., 7: 129-141.

Bajaj A., Lohan P., Jha P.N., Mehrotra R. (2010). Biodiesel production through lipase catalyzed transesterification: an overview. J. Mol. Catal. B Enzym., 62: 9-14.

B ansal M., Fu Y., A 1 rubaye B., Abraha M., A 1 mansour A., Gupta A., Liy anage R., Wang H., Harg is B., S un X. (2020). A secondary bile acid from microbiota metabolism attenuates ileitis and bile acid reduction in subclinical necrotic enteritis in chickens. J. Anim. Sci. Biotechnol., 11: 1-10.

B e a u chemin K., Colombat to D., Morgavi D., Yang W. (2003). Use of exogenous fibrolytic enzymes to improve feed utilization by ruminants. J. Anim. Sci., 81: E37-E47.

B e cker W.A., S pencer J.V., Mirosh L.W., Verstrate J.A. (1979). Prediction of fat and fat free live weight in broiler chickens using backskin fat, abdominal fat, and live body weight. Poultry Sci., 58: 835-842. 
B e g l e y M., G a h a n C.G., H 111 C. (2005). The interaction between bacteria and bile. FEMS Microbiol. Rev., 29: 625-651.

B e n j a m in S., Pand e y A. (1998). Candida rugosa lipases: molecular biology and versatility in biotechnology. Yeast, 14: 1069-1087.

B e r g s trö m S., D a n i e l s s on H., K a z u n o T. (1960). Bile acids and steroids. 98. The metabolism of bile acids in python and constrictor snakes. J. Biol. Chem., 235: 983-988.

Bontempo V., Comi M., Jiang X., Rebucci R., Caprarulo V., Giromini C., Got t a rdo D., F u s i E., S t e 11 a S., T ir l o n i E. (2018). Evaluation of a synthetic emulsifier product supplementation on broiler chicks. Anim. Feed Sci. Technol., 240: 157-164.

B o ontiam W., Jung B., Kim Y. (2016). Effects of lysophospholipid supplementation to lower nutrient diets on growth performance, intestinal morphology, and blood metabolites in broiler chickens. Poultry Sci., 96: 593-601.

B or a L., G o ha in D., D a s R. (2013). Recent advances in production and biotechnological applications of thermostable and alkaline bacterial lipases. J. Chem. Technol. Biot., 88: 1959-1970.

B org strom B., B arrow man J., Krabis ch L., Lind ström M., Lilli en a u J. (1986). Effects of cholic acid, 7 $\beta$-hydroxy-and $12 \beta$-hydroxy-isocholic acid on bile flow, lipid secretion and bile acid synthesis in the rat. Scand. J. Clin. Lab. Invest., 46: 167-175.

B orrelli G., Tron o D. (2015). Recombinant lipases and phospholipases and their use as biocatalysts for industrial applications. Int. J. Mol. Sci., 16: 20774-20840.

B rabcová J., Demianová Z., Vondrášek J., Jág r M., Zarevúcka M., Pa lo mo J.M. (2013). Highly selective purification of three lipases from Geotrichum candidum 4013 and their characterization and biotechnological applications. J. Mol. Catal. B Enzym., 98: 62-72.

Brenes A., Centeno C., Viveros A., Arija I. (2008). Effect of enzyme addition on the nutritive value of high oleic acid sunflower seeds in chicken diets. Poultry Sci., 87: 2300-2310.

Brígida A.I., Amaral P.F., Coelho M.A., Goncalves L.R. (2014). Lipase from Yarrowia lipolytica: production, characterization and application as an industrial biocatalyst. J. Mol. Catal. B Enzym., 101: 148-158.

Caballe ro V., B a u t is ta F.M., C a mpelo J.M., L una D., Marin a s.M., Ro mero A.A., Hi d a l g o J.M., L u que R., M a c ario A., Giordano G. (2009). Sustainable preparation of a novel glycerol-free biofuel by using pig pancreatic lipase: Partial 1, 3-regiospecific alcoholysis of sunflower oil. Process Biochem., 44: 334-342.

Cantafora A., Alvaro D., Attili A., Di A.B., Anza M., Mantovani A., Angelico M. (1986). Hepatic 3 alpha-dehydrogenation and 7 alpha-hydroxylation of deoxycholic acid in the guinea-pig. Comp. Biochem. Physiol. B Comp. Biochem., 85: 805-810.

Cas a s-Godoy L., Gasteazoro F., Duquesne S., B ordes F., Marty A., S andoval G. (2018). Lipases: an overview. Lipases and Phospholipases. Humana Press, New York, pp. 3-38 .

C a s p a ry W.F. (1992). Physiology and pathophysiology of intestinal absorption. Am. J. Clin. Nutr., 55: 299S-308S.

Chang S.-W., Shaw J.-F., S h i e h C.-J. (2003). Optimization of enzymatically prepared hexyl butyrate by lipozyme IM-77. Food Technol. Biotechnol., 41: 237-242.

Ch e a h Y., L o h T., A k it H., K i m k o o 1 S. (2017). Effect of synthetic emulsifier and natural biosurfactant on feed process and quality of pelletized feed in broiler diet. Braz. J. Poult. Sci., 19: 23-34.

Cho J.H., Z h a o P., Kim I.H. (2012). Effects of emulsifier and multi-enzyme in different energy density diet on growth performance, blood profiles, and relative organ weight in broiler chickens. J. Agric. Sci., 4: 161-168.

Class en H.L. (2017). Diet energy and feed intake in chickens. Anim. Feed Sci. Technol., 233: $13-21$.

Coello A., Meijide F., Núñez E.R., Tato J.V. (1996). Aggregation behavior of bile salts in aqueous solution. J. Pharm. Sci., 85: 9-15.

C o le m a n R. (1987). Bile salts and biliary lipids. Biochem. Soc. Trans., 15: 68S-80S. https://www. ncbi.nlm.nih.gov/pubmed/3328715.

Collar C., Martinez J., Andreu P., Armero E. (2000). Effects of enzyme associations on bread dough performance. A response surface analysis/Efectos de las asociaciones enzimáticas sobre la calidad funcional de masas panarias. Análisis de superficies de respuesta. Food Sci. Technol. Int., 6: 217-226. 
Conde-Aguilera J.A., Cobo-Ortega C., Tesseraud S., Lessire M., Mercier Y., Van M.J. (2013). Changes in body composition in broilers by a sulfur amino acid deficiency during growth. Poultry Sci., 92: 1266-1275.

C ow i e s o n A., A d e o la O. (2005). Carbohydrases, protease, and phytase have an additive beneficial effect in nutritionally marginal diets for broiler chicks. Poultry Sci., 84: 1860-1867.

D abbou S., S chi avone A., Gai F., Martinez S., Madrid J., Hernandez F., Martínez M a rín A.L., S o g 1 i a D., S a r t o r e S., K a $1 \mathrm{~m}$ a r I.D. (2019). Effect of dietary globin, a natural emulsifier, on the growth performance and digestive efficiency of broiler chickens. Ital. J. Anim. Sci., 18: 530-537.

D a n i c k e S. (2001). Identity and fat quality and content in response to feed enzymes in broilers. Enzymes in Farm Animal Nutrition. ed. CABI Pub, Wallingford, UK.

Dantas A., Valéri o A., N in ow J.L., de Oliveira J.V., de Oliveira D. (2019). Potential application of Thermomyces lanuginosus lipase (TLL) immobilized on nonporous polystyrene particles. Environ. Prog. Sustain. Energy., 38: 608-613.

de Morais Júnior W.G., Maia A.M., Martins P.A., Fernández-Lorente G., Guis á n J.M., P e s s e la B.C. (2018). Influence of different immobilization techniques to improve the enantioselectivity of lipase from Geotrichum candidum applied on the resolution of mandelic acid. Mol. Catal., 458: 89-96.

D e vli in T. (2006). Textbook of biochemistry with clinical correlations. John Wiley and Sons. New York.

D ha ke K.P., Th a k a re D.D., B h a n a g e B.M. (2013). Lipase: a potential biocatalyst for the synthesis of valuable flavour and fragrance ester compounds. Flavour Frag. J., 28: 71-83.

Di Ciaula A., Garruti G., Lunardi Baccetto R., Molina-Molina E., Bonfrate L., Wang D.Q., P ortin c a s a P. (2018). Bile acid physiology. Ann. Hepatol., 16: 4-14.

D un c an R.E., A h m a di a n M., J aw or s ki K., S a r k a d i-N a g y E., S u 1 H.S. (2007). Regulation of lipolysis in adipocytes. Annu. Rev. Nutr., 27: 79-101.

Dunning to n E.A., S i e g e 1 P. (1995). Enzyme activity and organ development in newly hatched chicks selected for high or low eight-week body weight. Poultry Sci., 74: 761-770.

E 1 k in R.G., Wo o d K., H a g e y L. (1990). Biliary bile acid profiles of domestic fowl as determined by high performance liquid chromatography and fast atom bombardment mass spectrometry. Comp. Biochem. Physiol. B Comp. Biochem., 96: 157-161.

E 1 z o b i e r M., I b r a h i m M.T.E., E 1 b a s h i e r O.M. (2016). Effects of dietary inclusion of fish oil on broiler performance and feed utilization. Int. J. Sci. Technol. Res., 5: 77-89.

Enge l king L.R. (2011). Textbook of veterinary physiological chemistry. Academic Press, Elsevier, The Boulevard, Langford Lane, Kidlington, Oxford, UK.

Fallahi P., Habte-Tsion H.M., Rossi W. (2018). Depolymerizating enzymes in human food: bakery, dairy products, and drinks, enzymes in human and animal nutrition. Elsevier, pp. 211-237.

F a s c in a V., Carrijo A., S ouza K., Garcia A., Ki efer C., S a r tori J.R. (2009). Soybean oil and beef tallow in starter broiler diets. Braz. J. Poult. Sci., 11: 249-256.

Febel H., Mezes M., Palfy T., Herman A., Gundel J., Lugasi A., Balogh K., Kocs i s I., B l a z o v i c s A. (2008). Effect of dietary fatty acid pattern on growth, body fat composition and antioxidant parameters in broilers. J. Anim. Physiol. Anim. Nutr., 92: 369-376.

F ern a n d e z - L a fuente R. (2010). Lipase from Thermomyces lanuginosus: uses and prospects as an industrial biocatalyst. J. Mol. Catal. B Enzym., 62: 197-212.

F i ckers P., M arty A., N i c a u d J.M. (2011). The lipases from Yarrowia lipolytica: genetics, production, regulation, biochemical characterization and biotechnological applications. Biotechnol. Adv., 29: 632-644.

F i r m a n J.D., K a m y a b A., L e ig h H. (2008). Comparison of fat sources in rations of broilers from hatch to market. Int. J. Poultry Sci., 7: 1152-1155.

Franken L.P.G., M a r c o n N.S., Tre i che l H., O live ir a D., F re i r e D.M., D a ri v a C., D e s t a in J., O live ir a J.V. (2010). Effect of treatment with compressed propane on lipases hydrolytic activity. Food Bioproc. Tech., 3: 511-520.

Fre e man C. (1984). The digestion, absorption and transport of fats: non-ruminants. Proc. Easter School in Agricultural Science, University of Nottingham. 
García-Silvera E.E., Martínez-Morales F., Bertrand B., Morales-Guzmán D., Ros a s-Galván N.S., León-Rodríguez R., Trejo-Hernández M.R. (2018). Production and application of a thermostable lipase from Serratia marcescens in detergent formulation and biodiesel production. Biotechnol. Appl. Biochem., 65: 156-172.

Garrett R., Young R. (1975). Effect of micelle formation on the absorption of neutral fat and fatty acids by the chicken. J. Nutr., 105: 827-838.

Garruti G., Wang H.H., B onfrate L., d e B ari O., Wang D.Q.-H., P ortinc a s a P. (2012). A pleiotropic role for the orphan nuclear receptor small heterodimer partner in lipid homeostasis and metabolic pathways. J. Lipids, 22.

Ge X., Wang A., Ying Z., Zhang L., Su W., Cheng K., Feng C., Zhou Y., Zhang L., Wan g T. (2018). Effects of diets with different energy and bile acids levels on growth performance and lipid metabolism in broilers. Poultry Sci., 98: 887-895.

Goto T., Holzinger F., Hagey L., Cerrè C., Ton-Nu H., Schteingart C., Steinbach J., Shneider B., Hofmann A. (2003). Physicochemical and physiological properties of $5 \alpha$-cyprinol sulfate, the toxic bile salt of cyprinid fish. J. Lipid Res., 44: 1643-1651.

G u X., L i D. (2003). Fat nutrition and metabolism in piglets: a review. Anim. Feed Sci. Technol., 109: 151-170.

Guerreiro Neto A., Pezzato A.C., Sartori J.R., Mori C., Cruz V., Fas cina V., Pinhe iro D., M a de ir a L., G on ç a lvez J. (2011). Emulsifier in broiler diets containing different fat sources. Braz. J. Poult. Sci., 13: 119-125.

Guertin F., L or anger A., L e p a g e G., R o y C.C., You s e f I.M., D o m ing o N., Chanus s ot F., Lafont H., Tuchweber B. (1995). Bile formation and hepatic plasma membrane composition in guinea-pigs and rats. Comp. Biochem. Physiol. Part B: Biochem. Mol. Biol., 111: $523-531$.

Gunst on e F.D. (2012). Fatty acid and lipid chemistry. Springer.

Hackett S.J., Kimball R.T., Reddy S., Bowie R.C., Braun E.L., Braun M.J., Chojnow s k i J.L., C ox W.A., Han K.-L., Harsh man J. (2008). A phylogenomic study of birds reveals their evolutionary history. Science, 320: 1763-1768.

H a g e y L.R., S c h t e ing art C.D., To n - N u H.-T., H o f m a n n A.F. (1994). Biliary bile acids of fruit pigeons and doves (Columbiformes): presence of 1-beta-hydroxychenodeoxycholic acid and conjugation with glycine as well as taurine. J. Lipid Res., 35: 2041-2048.

H a g e y L.R., G a vrilkin a M.A., H o fm a n n A.F. (1997). Age-related changes in the biliary bile acid composition of bovids. Can. J. Zool., 75: 1193-1201.

Hag e y L.R., Mølle r P.R., Ho fmann A.F., Kra s ow ski M.D. (2010). Diversity of bile salts in fish and amphibians: evolution of a complex biochemical pathway. Physiol. Biochem. Zool. 83: 308-321.

Hamosh M., Bitman J., Lia o T.H., Mehta N., Buczek R., Wood D., Grylack L., $\mathrm{H}$ a m o s h P. (1989). Gastric lipolysis and fat absorption in preterm infants: effect of medium-chain triglyceride or long-chain triglyceride-containing formulas. Pediatrics, 83: 86-92.

He D., B arnes S., F a lan y C.N. (2003). Rat liver bile acid CoA: amino acid N-acyltransferase expression, characterization, and peroxisomal localization. J. Lipid Res., 44: 2242-2249.

He 11 o u J., K ing A., N i I. (1988). Bile acids from the harp seals, Phoca groenlandica. Comp. Biochem. Physiol. A Comp. Physiol., 89: 211-214.

Hemati Matin H., Shariatmadari F., Karimi Torshizi M., Chiba L. (2016). In vitro bile acid-binding capacity of dietary fibre sources and their effects with bile acid on broiler chicken performance and lipid digestibility. Brit. Poultry Sci., 57: 348-357.

H e r m i e r D. (1997). Lipoprotein metabolism and fattening in poultry. J. Nutr., 127: 805S-808S.

H o fm a n n A.F. (1999). Bile acids: the good, the bad, and the ugly. Physiology, 14: 24-29.

H o f m a n n A.F., H a ge y L.R. (2014). Key discoveries in bile acid chemistry and biology and their clinical applications: history of the last eight decades. J. Lipid Res., 55: 1553-1595.

H o f m a n n A.F., M o s b a ch E.H. (1964). Identification of allodeoxycholic acid as the major component of gallstones induced in the rabbit by $5 \alpha$-cholestan-3 $\beta$-ol. J. Biol. Chem., 239: 2813-2821.

H o fm a n n A.F., H a g e y L.R., K r a s o w s k i M.D. (2010). Bile salts of vertebrates: structural variation and possible evolutionary significance. J. Lipid Res., 51: 226-246.

H o s h it a T. (1967). Stero-bile acids and bile alcohols. J. Biochem., 61: 440-449. 
Hos s e in i S.M., Nourmohammadi R., Nazarizadeh H., Lat shaw J.D. (2018). Effects of lysolecithin and xylanase supplementation on the growth performance, nutrient digestibility and lipogenic gene expression in broilers fed low-energy wheat-based diets. J. Anim. Physiol. Anim. Nutr., 102: 1564-1573.

Hu Y., Lan D., Zhu Y., P ang H., Mu X., Hu X. (2018). Effect of diets with different energy and lipase levels on performance, digestibility and carcass trait in broilers. Asian-Australas. J. Anim. Sci., 31: 1275-1284.

Huang J., Yang D., Ga o S., Wang T. (2008). Effects of soy-lecithin on lipid metabolism and hepatic expression of lipogenic genes in broiler chickens. Livest. Sci., 118: 53-60.

H u a n g W.-C., C h e n C.-Y., W u S.-J. (2017). Almond skin polyphenol extract inhibits inflammation and promotes lipolysis in differentiated 3T3-L1 adipocytes. J. Med. Food, 20: 103-109.

Hu h t a n e n C. (1979). Bile acid inhibition of Clostridium botulinum. Appl. Environ. Microbiol., 38: $216-218$.

Hurwitz S., Bar A., Katz M., Sklan D., Budowski P. (1973). Absorption and secretion of fatty acids and bile acids in the intestine of the laying fowl. J. Nutr., 103: 543-547.

Jaeger K.-E., Ransac S., Dijkstra B.W., Colson C., van Heuvel M., Misset O. (1994). Bacterial lipases. FEMS Microbiol. Rev., 15: 29-63.

J o J.C., K i m S.-J., K i m H.K. (2014). Transesterification of plant oils using Staphylococcus haemolyticus L62 lipase displayed on Escherichia coli cell surface using the OmpA signal peptide and EstA $\beta 8$ anchoring motif. Enzym. Microb. Tech., 67: 32-39.

J o h n s o n E.A. (2013). Biotechnology of non-Saccharomyces yeasts - the ascomycetes. Appl. Microbiol. Biotechnol., 97: 503-517.

Kakiyama G., Iida T., Yoshimoto A., Goto T., Mano N., Goto J., Nambara T.,

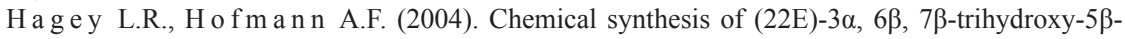
chol-22-en-24-oic acid and its taurine and glycine conjugates a major bile acid in the rat. J. Lipid Res., 45: 567-573.

K a k i y a ma G., I i d a T., G o to T., Ma no N., G o to J., N a m b a ra T., Hage y L.R., S chte in g a r t C.D., H o f m a n n A.F. (2006). Identification of a novel bile acid in swans, tree ducks, and geese: $3 \alpha, 7 \alpha, 15 \alpha$-trihydroxy-5 $\beta$-cholan-24-oic acid. J. Lipid Res., 47: 1551-1558.

Kaki y a ma G., Tamegai H., I ida T., Mitamura K., Ikegawa S., Goto T., Mano N., G o t o J., H o 1 z P., H a g e y L.R. (2007). Isolation and chemical synthesis of a major, novel biliary bile acid in the common wombat (Vombatus ursinus): $15 \alpha$-hydroxylithocholic acid. J. Lipid Res., 48: 2682-2692.

Kallner A., Knuts son L., Larsen B., Dumanovic J. (1967). On the biosynthesis and metabolism of allodeoxycholic acid in the rat. Acta Chem. Scand., 21: 315-321.

Kamiya S., Nagino M., Kanazawa H., Komatsu S., Mayumi T., Takagi K., Asahara T., N o m o to K., Tan a ka R., N i m u r a Y. (2004). The value of bile replacement during external biliary drainage: an analysis of intestinal permeability, integrity, and microflora. Ann. Surg., 239: 510.

K a p o or M., G u p t a M.N. (2012). Lipase promiscuity and its biochemical applications. Process Biochem., 47: 555-569.

Knarreborg A., Jensen S.K., Engberg R.M. (2003). Pancreatic lipase activity as influenced by unconjugated bile acids and $\mathrm{pH}$, measured in vitro and in vivo. J. Nutr. Biochem., 14: 259-265.

K o c s a r L., B e r to k L., Vartere s z V. (1969). Effect of bile acids on the intestinal absorption of endotoxin in rats. J. Bacteriol., 100: 220-223.

Ko op I., Schindler M., B os shammer A., S cheibner J., Stange E., Koop H. (1996). Physiological control of cholecystokinin release and pancreatic enzyme secretion by intraduodenal bile acids. Gut, 39: 661-667.

Krogdah 1 Å. (1985). Digestion and absorption of lipids in poultry. J. Nutr., 115: 675-685.

Krog dah $1 \AA$., S e 11 J.L. (1989). Influence of age on lipase, amylase, and protease activities in pancreatic tissue and intestinal contents of young turkeys. Poultry Sci., 68: 1561-1568.

Kum ar S., M a thur A., S ing h V., N and y S., K h are S.K., N e g i S. (2012). Bioremediation of waste cooking oil using a novel lipase produced by Penicillium chrysogenum SNP5 grown in solid medium containing waste grease. Bioresour. Technol., 120: 300-304. 
Kuramoto T., Moriwaki S., Kaw a moto K., Hos hita T. (1987). Intestinal absorption and metabolism of homourso deoxycholic acid in rats. J. Pharmacobio-Dyn., 10: 309-316.

Kurogi K., Krasowski M.D., Injeti E., Liu M.-Y., Williams F.E., Sakakibara Y., S u i k o M., L i u M.-C. (2011). A comparative study of the sulfation of bile acids and a bile alcohol by the Zebra danio (Danio rerio) and human cytosolic sulfotransferases (SULTs). J. Steroid. Biochem., 127: 307-314.

Lai W., Ca o A., Li J., Zhang W., Z hang L. (2018 a). Effect of high dose of bile acids supplementation in broiler feed on growth performance, clinical blood metabolites and organ development. J. Appl. Poultry Res., 27: 532-539.

Lai W., Huang W., Dong B., Cao A., Zhang W., Li J., Wu H., Zhang L. (2018 b). Effects of dietary supplemental bile acids on performance, carcass characteristics, serum lipid metabolites and intestinal enzyme activities of broiler chickens. Poultry Sci., 97: 196-202.

L a m m a s a k K., Ki j p a r k or n S., A n g k a n a p or n K. (2018). Porcine bile powder supplementation of a high fat broiler diet in relation to growth performance and nutrient digestion. Anim. Prod. Sci., 59: 1310-1317.

Lang D., Hofmann B., Ha lck L., Hecht H.-J., Spener F., Schmid R.D., Schomburg D. (1996). Crystal structure of a bacterial lipase from Chromobacterium viscosum ATCC 6918 refined at $1.6 \AA$ resolution. J. Mol. Biol., 259: 704-717.

Lee S., Le ster R., Pyrek J.S. (1987). Vulpecholic acid (1 alpha, 3 alpha, 7 alpha-trihydroxy-5 beta-cholan-24-oic acid): a novel bile acid of a marsupial, Trichosurus vulpecula (Lesson). J. Lipid Res., 28: 19-31.

L e e s o n S., S u m m e r s J. (2001). Scoot's Nutrition of the Chicken, Guelph, Canada.

Le e s on S., S u m mers J. (2005). Commercial Poultry Production. University Books, Guelph, Ontario, Canada.

Lefebvre P., Cariou B., Lien F., Ku ipers F., S taels B. (2009). Role of bile acids and bile acid receptors in metabolic regulation. Physiol. Rev., 89: 147-191.

Lehninger A.L., Nels on D.L., C ox M.M., Cox M.M. (2005). Lehninger Principles of Biochemistry. 4th ed., New York.

L i a o T.H., H a m o s h P., H a m o s h M. (1984). Fat digestion by lingual lipase: mechanism of lipolysis in the stomach and upper small intestine. Pediatr. Res., 18: 402.

L in d s a y O., March B. (1967). Intestinal absorption of bile salts in the cockerel. Poultry Sci., 46: $164-168$.

Lisbona F., Jimenez R., Esteller A., L opez M. (1981). Basal biliary secretion in conscious chicken and role of enterohepatic circulation. Comp. Biochem. Physiol. Part A: Physiol., 69: $341-344$.

L i u W.-C., K i m I.-H. (2017). Effects of dietary xylanase supplementation on performance and functional digestive parameters in broilers fed wheat-based diets. Poultry Sci., 96: 566-573.

L i ve ze y B.C., Z u s i R.L. (2007). Higher-order phylogeny of modern birds (Theropoda, Aves: Neornithes) based on comparative anatomy. II. Analysis and discussion. Zool. J. Linnean Soc., 149: $1-95$.

Maiorka A., Santin E., Silva A., Routman K., Pizauro Jr J., Macari M. (2004). Effect of broiler breeder age on pancreas enzymes activity and digestive tract weight of embryos and chicks. Braz. J. Poult. Sci., 6: 19-22.

Maisonnier S., Gomez J., B ree A., B erri C., B a eza E., Carre B. (2003). Effects of microflora status, dietary bile salts and guar gum on lipid digestibility, intestinal bile salts, and histomorphology in broiler chickens. Poultry Sci., 82: 805-814.

M a r i n J.J. (2008). How we have learned about the complexity of physiology, pathobiology and pharmacology of bile acids and biliary secretion. World J. Gastroentero., 14: 5617-5619.

Mar in J.J.M.J., M a c i a s R.M.R.I., B ri z O.B.O., B a na le s J.B.J.M., M o n te M.M.M.J. (2016). Bile acids in physiology, pathology and pharmacology. Curr. Drug Metab., 17: 4-29.

M a r i in C.R. (2015). Lipids and fatty acids in the preterm infant, part 1: basic mechanisms of delivery, hydrolysis, and bioavailability. NeoReviews, 16: e160-e168.

M a t e o s G.G., S e 11 J.L., E a s t w o o d J.A. (1982). Rate of food passage (transit time) as influenced by level of supplemental fat. Poultry Sci., 61: 94-100.

M e a d J.F. (1986). Lipids: Chemistry, Biochemistry, and Nutrition. Plenum Press. 
Meng X., Slominski B., Guenter W. (2004). The effect of fat type, carbohydrase, and lipase addition on growth performance and nutrient utilization of young broilers fed wheat-based diets. Poultry Sci., 83: 1718-1727.

Merrill J., Schteingart C., Hagey L., Peng Y., Ton-Nu H., Frick E., Jirsa M., $\mathrm{H}$ ofmann A. (1996). Hepatic biotransformation in rodents and physicochemical properties of 23 (R)-hydroxychenodeoxycholic acid, a natural alpha-hydroxy bile acid. J. Lipid Res., 37: 98-112.

M e y e r A., Z a rd o y a R. (2003). Recent advances in the (molecular) phylogeny of vertebrates. Annu. Rev. Ecol. Evol. Syst., 34: 311-338.

Mille r G., Mille r N. (1975). Plasma-high-density-lipoprotein concentration and development of ischaemic heart-disease. Lancet, 305: 16-19.

Minning S., Schmidt-Dannert C., Schmid R.D. (1998). Functional expression of Rhizopus oryzae lipase in Pichia pastoris: high-level production and some properties. J. Biotechnol., 66: 147-156.

Moham madighe is a r M., K i m H.S., Ki m I.H. (2018). Effect of inclusion of lysolecithin or multi-enzyme in low energy diet of broiler chickens. J. Appl. Anim. Res., 46: 1198-1201.

Monte M.J., Marin J.J., An te lo A., Vazquez-Tato J. (2009). Bile acids: chemistry, physiology, and pathophysiology. World J. Gastroentero., 15: 804-816.

Moreau J., Bou is on M., Saint-Marc-Girardin M., Pignal F., Bommelaer G., $\mathrm{R} i \mathrm{~b}$ e t A. (1988). Comparison of fungal lipase and pancreatic lipase in exocrine pancreatic insufficiency in man. Study of their in vitro properties and intraduodenal bioavailability. Gastroen. Clin. Biol., 12: 787-792.

Moschetta A., Xu F., Hagey L.R., van Berge-Henegouwen G.P., Van Erpecum K.J., Brouwers J.F., Cohen J.C., Bierman M., Hobbs H.H., Ste inbach J.H. (2005). A phylogenetic survey of biliary lipids in vertebrates. J. Lipid Res., 46: 2221-2232.

M u g l e r D., C u n n in g h a m F. (1972). Factors affecting poultry meat color - a review. Worlds Poultry Sci. J., 28: 400-406.

Murphy W.J., Eizirik E., Johns on W.E., Zhang Y.P., Ryder O.A., O ' B ri en S.J. (2001). Molecular phylogenetics and the origins of placental mammals. Nature, 409: 614-618.

Nagargoje S., Dhumal M., Nikam M., Khos e K. (2016). Effect of crude soy lecithin with or without lipase on performance and carcass traits, meat keeping quality and economics of broiler chicken. Int. J. Livest. Res., 6: 46-54.

Negi S. (2019). Lipases: a promising tool for food industry, green bio-processes. Springer, pp. $181-198$.

$\mathrm{N}$ ir I., N its a n Z., M a hag n a M. (1993). Comparative growth and development of the digestive organs and of some enzymes in broiler and egg type chicks after hatching. Brit. Poultry Sci., 34: $523-532$.

NRC (1994). Nutrient Requirements of Poultry. 9th rev. ed., Washington DC, National Academy of Sciences.

O ' C o n n or C.J., B a n g K.-A., T a y lor C.M., B r i m b le M.A. (2001). Determining the regio- and typo-selectivity of calf pregastric lipase. J. Mol. Catal. B Enzym., 16: 147-157.

Pand e y A., B e n j a m in S., S o c c o l C.R., N ig a m P., Kri e ger N., S o c c o l V.T. (1999). The realm of microbial lipases in biotechnology. Biotechnol. Appl. Bioc., 29: 119-131.

Pantay a D., Wid a y a t i A., J a d miko P., U t a mi M.M.D. (2020). Effect of bile acid supplementation in broiler feed on performance, carcass, cholesterol, triglycerides and blood glucose. In IOP Conference Series: Earth and Environmental Science, Indonesia, 411: 012041.

Parsaie S., Shariatmadari F., Zamiri M., Khajeh K. (2007). Influence of wheat-based diets supplemented with xylanase, bile acid and antibiotics on performance, digestive tract measurements and gut morphology of broilers compared with a maize-based diet. Brit. Poultry Sci., 48: 594-600.

P e d e r s e n J.I., G u s t a f s s o n J. (1980). Conversion of $3 \alpha, 7 \alpha, 12 \alpha$-trihydroxy-5 $\beta$-cholestanoic acid into cholic acid by rat liver peroxisomes. FEBS Lett., 121: 345-348.

Pér e z M.M., G on ça lve s E.C.S., Vi c i A.C., S a $1 \mathrm{~g}$ a d o J.C.S., d e M or a e s M.d.L.T. (2019). Fungal lipases: versatile tools for white biotechnology, recent advancement in white biotechnology through fungi. Springer, pp. 361-404. 
Piekarski A., Decuypere E., Buyse J., Dridi S. (2016). Chenodeoxycholic acid reduces feed intake and modulates the expression of hypothalamic neuropeptides and hepatic lipogenic genes in broiler chickens. Gen. Comp. Endocrinol., 229: 74-83.

P le is s J., F is cher M., S ch mid R.D. (1998). Anatomy of lipase binding sites: the scissile fatty acid binding site. Chem. Phys. Lipids, 93: 67-80.

P o 1 in D., Wing T.L., K i P., P e 11 K. (1980). The effect of bile acids and lipase on absorption of tallow in young chicks. Poultry Sci., 59: 2738-2743.

Pond W.G., Church D.C., P ond K.R., Schoknecht P.A. (2004). Basic animal nutrition and feeding. 5 th ed. John Wiley and Sons.

Prawitt J., Caron S., Staels B. (2011). Bile acid metabolism and the pathogenesis of type 2 diabetes. Curr. Diabetes Rep., 11: 160-166.

Prim oži č M., K a vč i č S., Kn e z Ž., L e it g e b M. (2016). Enzyme-catalyzed esterification of d, 1-lactic acid in different SCF/IL media. J. Supercrit. Fluids, 107: 414-421.

Rashid F.A.A., Rahim R.A., I brah im D., B a lan A., B a kar N.M.A. (2013). Purification and properties of thermostable lipase from a thermophilic bacterium, Bacillus licheniformis IBRL-CHS2. J. Pure Appl. Microbio., 7: 1635-1645.

R i d g w a y N., M c L e o d R. (2016). Biochemistry of lipids, lipoproteins and membranes. Elsevier.

R i d l o n J.M., K a n g D.-J., H y l e m o n P.B. (2006). Bile salt biotransformations by human intestinal bacteria. J. Lipid Res., 47: 241-259.

Rios N.S., Pinheiro B.B., Pinheiro M.P., B ezerra R.M., dos Santos J.C.S., Gonç a lv e s L.R.B. (2018). Biotechnological potential of lipases from Pseudomonas: sources, properties and applications. Process Biochem., 75: 99-120.

R odrigues C., Kren B.T., S t e e r C.J., S e t c he 11 K. (1996). Formation of delta 22-bile acids in rats is not gender specific and occurs in the peroxisome. J. Lipid Res., 37: 540-550.

R o s s i S.S., C o n v e r s e J.L., H o f m a n n A. (1987). High pressure liquid chromatographic analysis of conjugated bile acids in human bile: simultaneous resolution of sulfated and unsulfated lithocholyl amidates and the common conjugated bile acids. J. Lipid Res., 28: 589-595.

Rus s e 11 D.W. (2009). Fifty years of advances in bile acid synthesis and metabolism. J. Lipid Res., 50: S120-S125.

S a l a berría F., P a 11 a C., C a rrín M.E. (2017). Hydrolytic activity of castor bean powder: effect of gum arabic, lipase and oil concentrations. J. Am. Oil. Chem. Soc., 94: 741-745.

S a 1 e h A.A., A m b e r K.A., M o u s a M.M., N a d a A.L., Aw a d W., D aw o od M.A., E 1 - Mo ne im A.E., Ebeid T.A., A b d e l-D a i m M.M. (2020). A mixture of exogenous emulsifiers increased the acceptance of broilers to low energy diets: Growth performance, blood chemistry, and fatty acids traits. Animal, 10: 437.

Sánchez M., Prim N., Rández-Gil F., Pas tor F., Diaz P. (2002). Engineering of baker's yeasts, E. coli and Bacillus hosts for the production of Bacillus subtilis Lipase A. Biotechnol. Bioeng., 78: 339-345.

S a n y a 1 A.J., Hir s c h J.I., M o o r e E.W. (1994). Premicellar taurocholate enhances calcium uptake from all regions of rat small intestine. Gastroenterology, 106: 866-874.

S anz M., Lopez-B ote C.J., Men oy o D., B a u t ista J.M. (2000). Abdominal fat deposition and fatty acid synthesis are lower and $\beta$-oxidation is higher in broiler chickens fed diets containing unsaturated rather than saturated fat. J. Nutr., 130: 3034-3037.

S a ri c a S., C iftc i A., D e m ir E., K i l in c K., Y ild i r i m Y. (2005). Use of an antibiotic growth promoter and two herbal natural feed additives with and without exogenous enzymes in wheat based broiler diets. S. Afr. J. Anim. Sci., 35: 61-72.

S a v ory C., Gentle M. (1980). Intravenous injections of cholecystokinin and caerulein suppress food intake in domestic fowls. Experientia, 36: 1191-1192.

S c a n e s C.G. (2015). Sturkie's avian physiology. 6th ed. Academic Press, Elsevier, London.

S harma S., K a n w a r S.S. (2014). Organic solvent tolerant lipases and applications. Sci. World J., 15 pp., http://dx.doi.org/10.1155/2014/625258

S he en - Ch en S.-M., C h e n H.-S., H o H.-T., Ch e n W.-J., S h e en C.-C., En g H.-L. (2002). Effect of bile acid replacement on endotoxin-induced tumor necrosis factor - a production in obstructive jaundice. World J. Surg., 26: 448-450.

S i y a 1 F., B a b a z a d e h D., Wang C., A ra in M., S a e ed M., Ay a s a n T., Z hang L., Wang T. (2017). Emulsifiers in the poultry industry. Worlds Poultry Sci. J., 73: 611-620. 
S k 1 a n D. (1979). Digestion and absorption of lipids in chicks fed triglycerides or free fatty acids: synthesis of monoglycerides in the intestine. Poultry Sci., 58: 885-889.

S o c c o 1 C.R., Va n d e $\mathrm{n}$ b e r g h e L.P. (2003). Overview of applied solid-state fermentation in Brazil. Biochem. Eng. J., 13: 205-218.

Thom as C., Pelli c c iar i R., Pruzansk i M., A uw erx J., S choonjans K. (2008). Targeting bile-acid signalling for metabolic diseases. Nat. Rev. Drug Discov., 7: 678-693.

T h o m a s V.G., M a in g u y S.K., P r e ve tt J.P. (1983). Predicting fat content of geese from abdominal fat weight. J. Wildl. Manage., 47: 1115-1119.

U p a d h a y a S., L e e J.S., J un g K.J., K i m I. (2018). Influence of emulsifier blends having different hydrophilic-lipophilic balance value on growth performance, nutrient digestibility, serum lipid profiles, and meat quality of broilers. Poultry Sci., 97: 255-261.

Vi d a 1 N., H e d g e s S.B. (2009). The molecular evolutionary tree of lizards, snakes, and amphisbaenians. C. R. Biol., 332: 129-139.

Villeneuve P., Pina M., Graille J. (1996). Determination of pregastric lipase specificity in young ruminants. Chem. Phys. Lipids, 83: 161-168.

W a n g D.Q.-H., Ta zu ma S., C o hen D.E., C a r e y M.C. (2003). Feeding natural hydrophilic bile acids inhibits intestinal cholesterol absorption: studies in the gallstone-susceptible mouse. Am. J. Physiol. Gastrointest. Liver. Physiol., 285: G494-G502.

W a n g Y., Y an J., Z h a n g X., H a n B. (2018). Tolerance properties and growth performance assessment of Yarrowia lipolytic lipase in broilers. J. Appl. Anim. Res., 46: 486-491.

W a s h i z u T., To m o d a I., K a n e k o J.J. (1991). Serum bile acid composition of the dog, cow, horse and human. J. Vet. Med. Sci., 53: 81-86.

Wat an abe M., Houten S.M., Mataki C., Christoffolete M.A., Kim B.W., S at o H., Messaddeq N., Harney J.W., Ezaki O., Kod ama T. (2006). Bile acids induce energy expenditure by promoting intracellular thyroid hormone activation. Nature, 439: 484-489.

Webling D., Holdsworth E. (1965). The effect of bile, bile acids and detergents on calcium absorption in the chick. Biochem. J., 97: 408-421.

W i s e $m$ a n J., L e w is C. (1998). Influence of dietary energy and nutrient concentration on the growth of body weight and of carcass components of broiler chickens. J. Agric. Sci. 131: 361-371.

Wis e man J., S alvador F. (1989). Influence of age, chemical composition and rate of inclusion on the apparent metabolisable energy of fats fed to broiler chicks. Brit. Poultry Sci., 30: $653-662$.

W i s e m a n J., S a lva d or F., C ra i g on J. (1991). Prediction of the apparent metabolizable energy content of fats fed to broiler chickens. Poultry Sci., 70: 1527-1533.

W u G. (2018). Principles of animal nutrition. 1st ed. CRC Press, Boca Raton, Florida.

Xi a o Z., Hou X., Ly u X., Zha o J.-Y., Xi L., Li J., Lu J.R. (2015). Enzymatic synthesis of aroma acetoin fatty acid esters by immobilized Candida antarctica lipase B. Biotechnol. Lett., 37: $1671-1677$.

Yu X.-W., Wa n g L.-L., X u Y. (2009). Rhizopus chinensis lipase: gene cloning, expression in Pichia pastoris and properties. J. Mol. Catal. B Enzym., 57: 304-311.

Z a e farian F., A bdollah i M.R., Cow i e son A., R a vindran V. (2019). Avian liver: The forgotten organ. Animal, 9: 63.

Z a m p i g a M., M e l u z z i A., S irri F. (2016). Effect of dietary supplementation of lysophospholipids on productive performance, nutrient digestibility and carcass quality traits of broiler chickens. Ital. J. Anim. Sci., 15: 521-528.

Zechner R., Zimmermann R., Eichmann T.O., Kohlwein S.D., Haemmerle G., L a s s A., M a d e o F. (2012). Fat signals - lipases and lipolysis in lipid metabolism and signaling. Cell Metab., 15: 279-291.

Zentler-Munro P., Assoufi B., Balasubramanian K., Cornell S., Benoliel D., North field T., Hods on M. (1992). Therapeutic potential and clinical efficacy of acid-resistant fungal lipase in the treatment of pancreatic steatorrhoea due to cystic fibrosis. Pancreas, 7 : 311-319.

Zh ang B., Hait a o L., Z h a o D., Gu o Y., B arri A. (2011). Effect of fat type and lysophosphatidylcholine addition to broiler diets on performance, apparent digestibility of fatty acids, and apparent metabolizable energy content. Anim. Feed Sci. Technol., 163: 177-184. 
Zhang W., Yan C., Shen J., We i R., Gao Y., Mi a o A., Xi a o L., Yang L. (2019). Characterization of aerobic denitrifying bacterium Pseudomonas mendocina strain GL6 and its potential application in wastewater treatment plant effluent. Int. J. Environ. Res. Public Health, 16: 364-377.

$\mathrm{Z}$ h a o P., K i m I. (2017). Effect of diets with different energy and lysophospholipids levels on performance, nutrient metabolism, and body composition in broilers. Poultry Sci., 96: 1341-1347.

Zheng J., X i e B.-H., C h e n Y.-L., C a o J.-F., Yang Y., G u a n Z., H e Y.-H. (2014). Direct asymmetric aldol reactions catalyzed by lipase from porcine pancreas. Z. Naturforsch. C., 69: 170-180.

Z hu Q.-F., H u ang J., Yang D.-D., Wang T. (2008). Effects of soybean lecithin supplementation on production performance, carcass quality and serum biochemical parameters in broilers. Acta Ecol. Anim. Domast., 5. http://en.cnki.com.cn/Article_en/CJFDTotal-JCST200805011.htm

Z in N.B.M., Yu s of B.M., O s lan S.N., Was oh H., Tan J.S., A riff A.B., H a li m M. (2017). Utilization of acid pre-treated coconut dregs as a substrate for production of detergent compatible lipase by Bacillus stratosphericus. AMB Express, 7: 131-143.

Received: 17 V 2020

Accepted: 9 IX 2020 